Aquatic Plant Control Research Program

\title{
Potential Use of Native and Naturalized Insect Herbivores and Fungal Pathogens of Aquatic and Wetland Plants
}

Jan E. Freedman, Michael J. Grodowitz,

August 2007

Robin Swindle, and Julie G. Nachtrieb 


\section{Potential Use of Native and Naturalized Insect Herbivores and Fungal Pathogens of Aquatic and Wetland Plants}

Jan E. Freedman and Michael J. Grodowitz

Environmental Laboratory

U.S. Army Engineer Research and Development Center

3909 Halls Ferry Road

Vicksburg, MS 39180-6199

Robin Swindle

Baylor University

Waco, TX 76704

Julie G. Nachtrieb

Lewisville Aquatic Ecosystem Research Facility

Lewisville, TX 75057

Final report

Approved for public release; distribution is unlimited. 


\begin{abstract}
Research is being conducted by U.S. Army Engineer Research and Development Center (ERDC) scientists to identify naturalized and/ or native herbivores of aquatic plants in an effort to develop alternative management strategies through an understanding of the agents' biology and ecology. Some of the native species showing promise as biocontrol agents include Altica spp. for water primrose, Donacia spp. for American lotus, and Euhrychiopsis lecontei for Eurasian watermilfoil control. Naturalized species with possibility include Cyrtobagus salviniae for common and giant salvinia, and Parapoynx diminutalis for hydrilla. Information is presented herein for selected native and naturalized agents that may potentially be used to impact and manage all types of aquatic and wetland plant species including introduced, naturalized, and native species. Native and naturalized insect herbivores and fungal pathogens discussed include: Acanthoscelides quadridentatus, Acentria ephemerella, Altica spp., Cyrotobagous salviniae, Donacia spp., Euhrychiopsis lecontei, Hydrellia bilobifera Cresson, $H$. discursa Deonier, Mycoleptodiscus terrestris, Ostrinia penitalis, Parapoynx diminutalis, Pergaster cretura, Simyra henrici, and Synclita oblieralis.
\end{abstract}

DISCLAIMER: The contents of this report are not to be used for advertising, publication, or promotional purposes. Citation of trade names does not constitute an official endorsement or approval of the use of such commercial products. All product names and trademarks cited are the property of their respective owners. The findings of this report are not to be construed as an official Department of the Army position unless so designated by other authorized documents. 


\section{Contents}

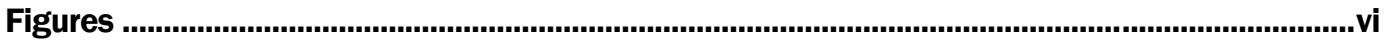

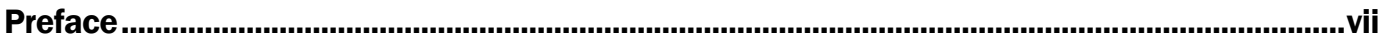

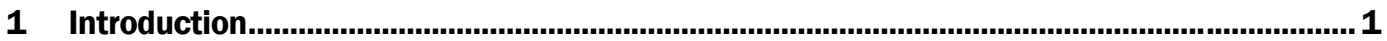

2 Purpose of Studying Native and Naturalized Insect Herbivores and Fungal

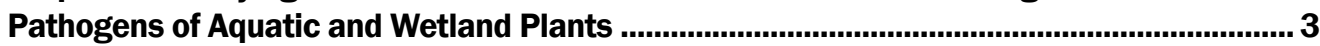

3 Native and Naturalized Insect Herbivores and Fungal Pathogens of Aquatic and

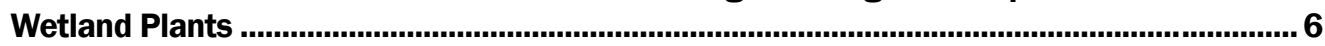

Acanthoscelides quadridentatus (Schaeffer) - Mimosa Seed Beetle (Coleoptera:

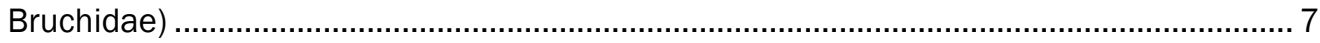

General Information and History.......................................................................................... 7

Biology

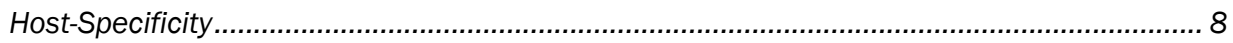

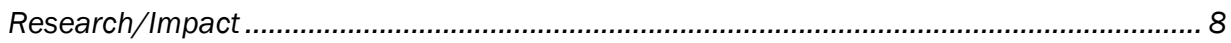

Possible Use in Control Programs .................................................................................. 9

Acentria ephemerella Denis and Schiffermuller (syn: Acentria nivea Oliver) -

Milfoil Moth, Water Veneer Moth (Lepidoptera: Pyralidae) ……........................................... 9

General Information and History ..................................................................................

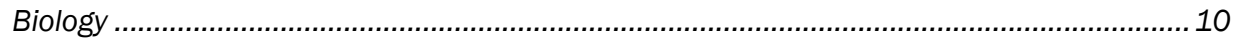

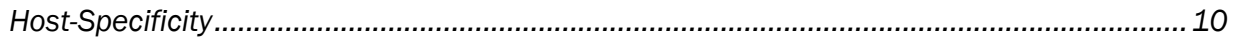

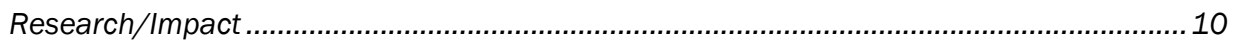

Possible Use in Control Programs ................................................................................ 11

Altica spp. - Flea Beetles; Leaf-Feeding Beetles; Water-Primrose Flea Beetle

(Coleoptera: Chrysomelidae: Halticinae) …..................................................................... 11

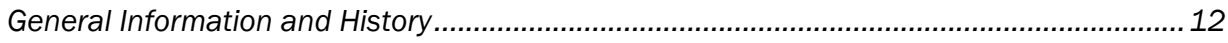

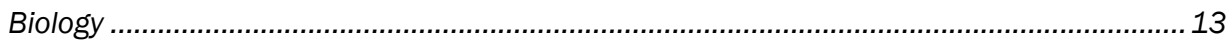

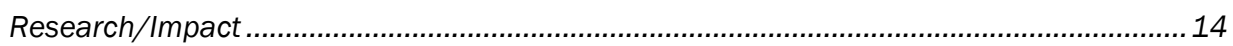

Possible Use in Control Programs ................................................................................... 14

Cyrtobagous salviniae Calder and Sands, Salvinia Weevil (Coleoptera:

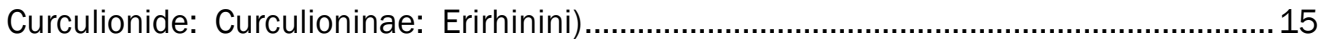

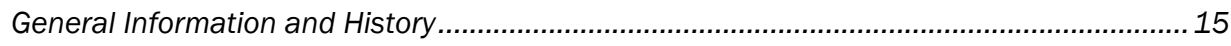

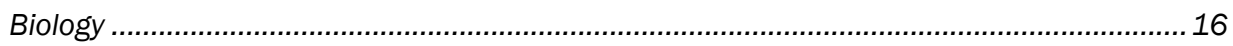

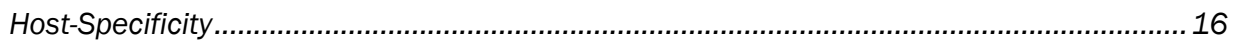

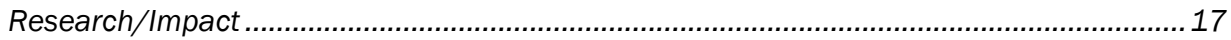

Possible Use in Control Programs ....................................................................................... 17

Donacia spp., Long-Horned Leaf Beetles (Coleoptera: Chrysomelidae:

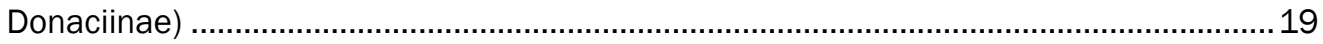

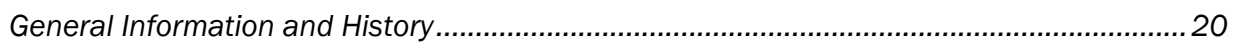

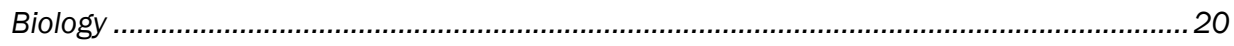

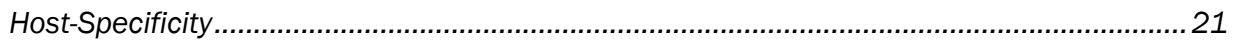

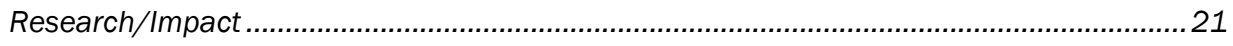


Possible Use in Control Programs ..................................................................................... 21

Euhrychiopsis lecontei (Dietz), Milfoil Weevil (Coleoptera: Curculionidae) ........................22

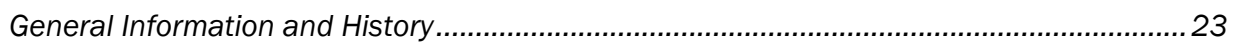

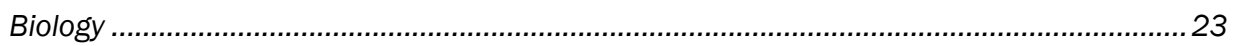

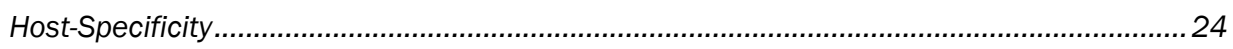

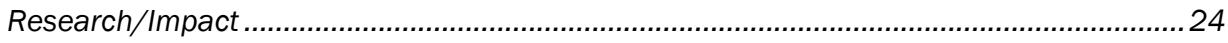

Possible Use in Control Programs ...................................................................................... 25

Hydrilla Leaf-mining Flies, Hydrellia bilobifera Cresson, and $H$. discursa Deonier

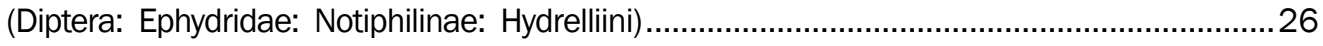

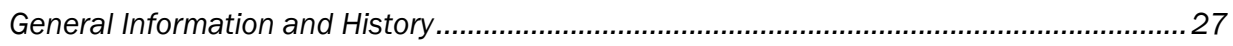

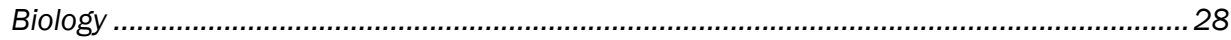

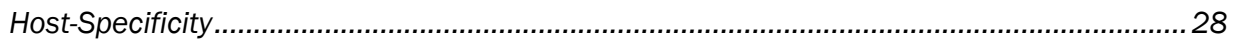

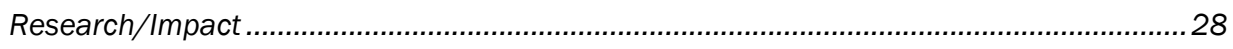

Possible Use in Control Programs ............................................................................................. 29

Mycoleptodiscus terrestris (Gerd.) Ostazeski Fungi, Ascomycota, Ascomycetes, Sordariomycetidae, Incertae sedis, Magnaporthaceae ................................................29

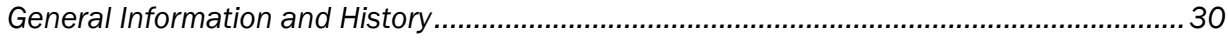

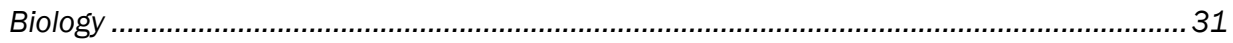

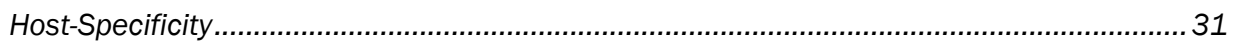

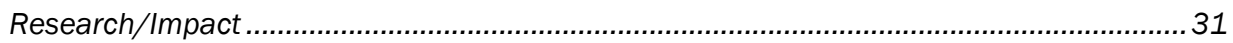

Possible Use in Control Programs .................................................................................... 32

Ostrinia penitalis (Grote), American Lotus Borer (Lepidoptera: Pyralidae:

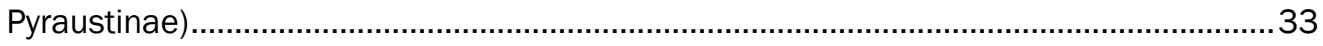

General Information and History .................................................................................. 33

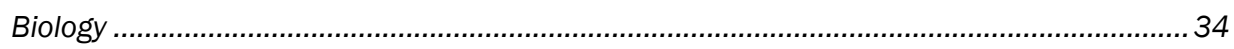

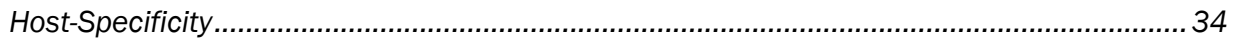

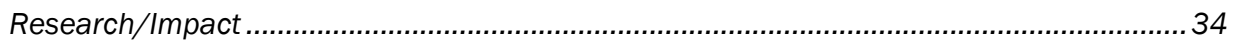

Possible Use in Control Programs ..................................................................................... 34

Parapoynx diminutalis Snellen, Asian Hydrilla Moth, (Lepidoptera: Pyralidae:

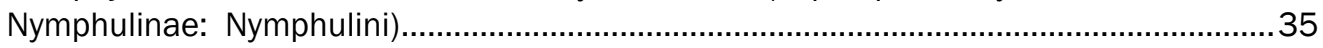

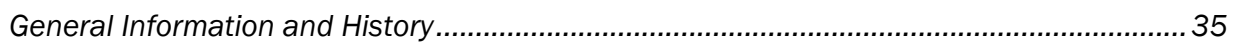

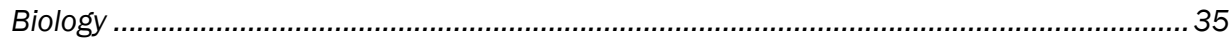

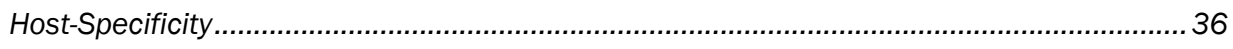

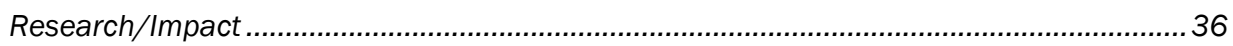

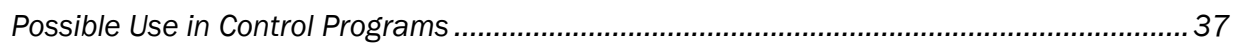

Perigaster cretura (Herbst), Primrose Leaf Weevil (Coleoptera: Curculionidae:

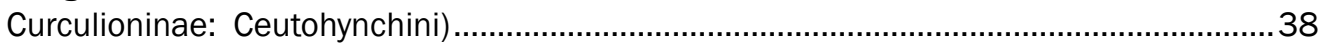

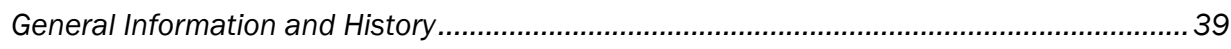

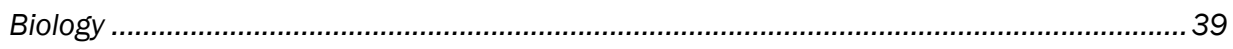

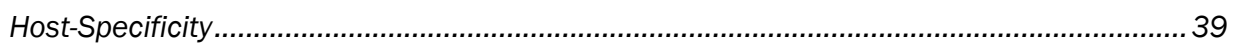

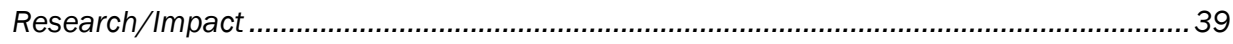

Possible Use in Control Programs ....................................................................................... 39

Simyra henrici (Grote), Cattail Caterpillar (Lepidoptera: Noctuidae: Acronictinae) ..........40

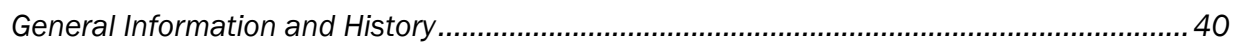

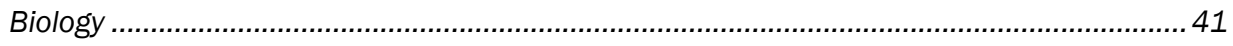

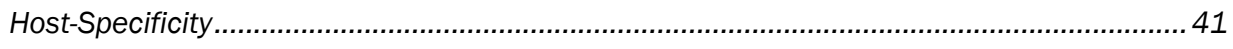

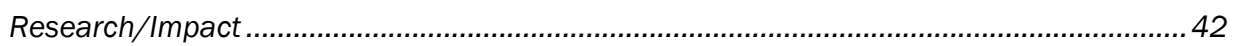


Possible Use in Control Programs .................................................................................... 42

Synclita obliteralis (Walker), Waterlily Leafcutter, (Lepidoptera: Pyralidae:

Nymphulinae: Nymphulini) ...................................................................................... 43

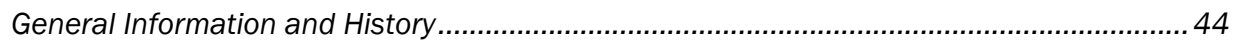

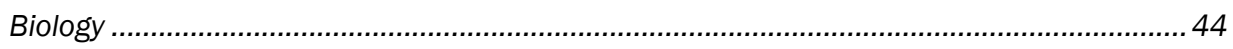

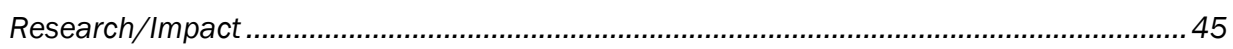

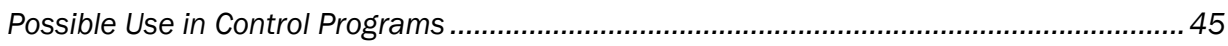

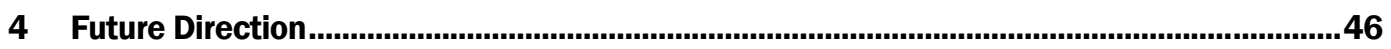

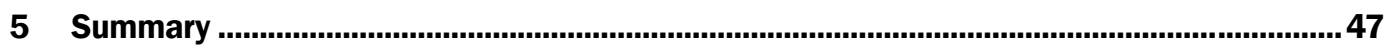

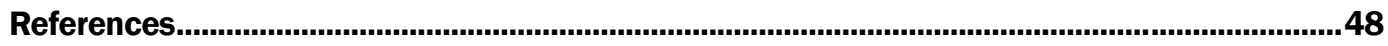

Report Documentation Page 


\section{Figures}

Figure 1. Mimosa seed beetle adult, eggs, and adult appearing in an exit hole. ……..................... 7

Figure 2. Milfoil moth larva and adult. ................................................................................ 9

Figure 3. Altica litigata Fall - Water-Primrose Flea Beetle adult damage, adult and eggs, eggs, larva, and pupa.

Figure 4. Water-primrose flea beetle adult and larvae. ..................................................................... 12

Figure 5. Primrose damaged by water-primrose flea beetle....................................................... 12

Figure 6. Salvinia weevil adults and damage............................................................................. 15

Figure 7. C. salviniae released in four ponds at LAERF - May 2004. Photograghs taken four months after release: (Pond A) $100 \mathrm{lb}$ ammonium sulfate every 2 weeks, (Pond B) 40 $\mathrm{lb}$ ammonium sulfate every 2 weeks, (Pond C) $10 \mathrm{lb}$ ammonium sulfate every 2 weeks, and (Pond D) not fertilized.

Figure 8. Eggs and adults of the long-horned leaf beetle.

Figure 9. Long-horned leaf beetle larvae feeding on a stalk of American Lotus, Lake

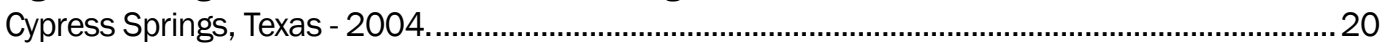

Figure 10. Milfoil weevil adults.................................................................................................... 22

Figure 11. Milfoil weevil larva in stem nearing pupation................................................................ 23

Figure 12. Female - Hydrellia bilobifera - cerci are long and narrow...............................................26

Figure 13. Female - Hydrellia discursa - cerci are short and round............................................... 26

Figure 14. Male - Hydrellia bilobifera - prominent lobes at the base of the abdomen................... 27

Figure 15. Male - Hydrellia discursa - no lobes at the base of the abdomen................................ 27

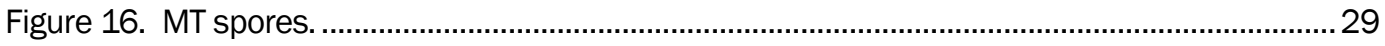

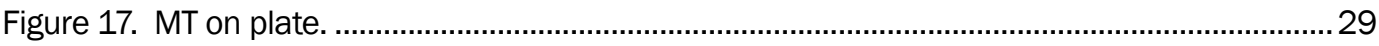

Figure 18. Mt aquaria study on hydrilla - the legend tells the amount of dry pathogen used (g), the experiment it came from (523), and the number of days the fermentation ran before harvesting (D).............................................................................................................. 30

Figure 19. American lotus borer, adult, larvae, and larval damage. ..................................................33

Figure 20. The Asian hydrilla moth larvae, adult, and damage to hydrilla........................................35

Figure 21. Primrose leaf weevil adult, cocoon, larva, and larval damage. .......................................38

Figure 22. Cattail caterpillar larva and adult............................................................................ 40

Figure 23. Waterlily leafcutter larva and larval damage................................................................. 43

Figure 24. Waterlily leafcutter adult........................................................................................ 44 


\section{Preface}

The work reported herein was conducted as part of the Aquatic Plant Control Research Program (APCRP), Work Unit 33189. The APCRP is sponsored by Headquarters, U.S. Army Corps of Engineers (HQUSACE), and is assigned to the U.S. Army Engineer Research and Development Center (ERDC), under the purview of the Environmental Laboratory (EL). Funding was provided under the Department of the Army Appropriation No. 96X3122, Construction General. Robert C. Gunkel, J r., EL, was Program Manager, APCRP. Program Monitor during this investigation was Timothy R. Toplisek, HQUSACE.

The principal investigator for this study was Dr. Michael J . Grodowitz, Aquatic Ecology and Invasive Species Branch, Ecosystem Evaluation and Engineering Division (EEED), EL. This report was prepared by J an E. Freedman, Dr. Michael J . Grodowitz, Robin Swindle, and J ulie G. Nachtrieb. At the time of preparation, Robin Swindle was located at Baylor University, Waco, TX. J ulie Nachtrieb is located at ERDC, Lewisville Aquatic Ecosystem Research Facility (LAERF), Lewisville, TX. The report was reviewed by Dr. Judy Shearer, EEED, and Chetta S. Owens, Analytical Services, Inc., LAERF.

This investigation was performed under the general supervision of Dr. Elizabeth C. Fleming, Director, EL; Dr. David J . Tazik, Chief, EEED, and Dr. Andrew C. Miller, former Branch Chief, Aquatic Ecology and Invasive Species Branch.

COL Richard B. J enkins was Commander and Executive Director of ERDC. Dr. J ames R. Houston was Director. 


\section{Introduction}

Many aquatic and wetland plant species cause tremendous problems across the country. These include impacts to biodiversity, navigation, irrigation, increased evaporation, as well as human health hazards (Anderson et al. 2005). Traditional control methods are varied and include management options such as chemical and mechanical strategies. While these methods produce satisfactory short-term control, other alternative methods that produce long-term and wide-scale impacts have been developed.

Alternative methods used to date have included the use of insect and fungal agents. Prime examples are the use of flea beetles for the management of alligatorweed (Alternanthera philoxeroides [Mart.] Griseb.), weevil species in the genus Neochetina to provide management for waterhyacinth (Eichhornia crassipes [Mart.] Solms.-Laubach), and the use of leaf-mining flies in the genus Hydrellia for hydrilla (Hydrilla verticillata (L.f.) Royle) control. In addition, progress has been made on the use of the fungal pathogen Mycoleptodiscus terrestris (Gerd.) Ostazeski for both hydrilla and Eurasian watermilfoil (Myriophyllum spicatum L.) management.

While traditional control methods have been employed successfully for introduced, native, and naturalized plant species, almost all biological control techniques are only directed towards introduced plant species. Most biological control projects involve exotic or introduced plant species that were accidentally or intentionally introduced into new environments minus their natural enemies. The goal of such projects is not eradication, but the reduction of a plant's abundance to a lower, more tolerable level (Goeden 1977). The process of obtaining biocontrol agents involves the importation (from the country of origin of the plant) and establishment of hostplant specific, crop-safe, plant-destructive natural enemies (Goeden 1977).

One of the fundamental concepts of biocontrol is that introduced and possibly native/ naturalized agents damage nuisance, invasive plants, thus slowing their growth (Goeden 1977). With a decrease in growth and growth potential, native plants can compete more favorably with the invasives. Classical biological control is based on the strategy that collecting natural enemies, i.e. parasites, predators, or pathogens of an invasive plant from its country of origin, and then releasing these organisms in places 
where it has become a nuisance will keep the plant's growth in check (Harley and Forno 1992). Identifying and obtaining these organisms is a lengthy process. It requires years of overseas research and extensive host testing to ensure that they are safe and will not attack any native, agronomic, or other plants deemed important in their introduced region (Harley and Forno 1992).

Traditionally these agents are from the same country as the invasive plant. In some cases, however, there are native or naturalized insects or pathogens already existing in the plant's introduced range that may help keep the invasive plant's growth below an economic threshold. The question becomes as to whether native or naturalized organisms would be successful biological control agents for introduced, nuisance plants. Equally important is whether native or naturalized agents are available to manage native and/ or naturalized aquatic and wetland plant species. 


\section{Purpose of Studying Native and Naturalized Insect Herbivores and Fungal Pathogens of Aquatic and Wetland Plants}

In addressing this issue, aquatic nuisance species program managers from Minnesota, Vermont, and Washington took part in a panel discussion on the "Management of Eurasian Watermilfoil in the United States Using Native Insects: State Regulatory and Management Issues" in 1998 (Madsen et al. 2000). While this panel specifically addressed Eurasian watermilfoil (EWM) issues, their ideas had wide application to the use of native and naturalized organisms for other species as well. The panel identified several positive and negative attributes for using native organisms. The use of native organisms: (1) is more popular with the general public than the use of exotic organisms (e.g., classical biological control) or herbicides;

(2) generally requires fewer regulatory steps; (3) is desirable if a selective and cost-effective biological control can be found; (4) is feasible if a costeffective method of propagation and distribution can be found; and (5) holds the promise for long-term control. Drawbacks included: (1) no state is prepared to embark on large-scale rearing of organisms for widespread distribution; (2) states are concerned about the introduction of new exotic pest species or insect parasites or pathogens brought in with the organisms from outside of the state; and (3) states are concerned about the introduction of more aggressive genotypes or other genotypes that may have less desirable attributes (e.g. lower fecundity or feeding rates). Additionally, the panel agreed that before native organisms could be widely used for managing nuisance aquatic plants, three issues needed to be addressed: (1) larger sources of these organisms are needed; (2) a practical approach needs to be developed to utilize native organisms that is both cost-effective and efficacious; and (3) consistent permitting or regulatory criteria need to be developed between states and at the federal level. Therefore, it is important to understand what impacts potential native/ naturalized herbivores are having not only on invasive species but on native plants as well. By doing so, biocontrol researchers can begin to:

1. Identify naturalized herbivores with potential as alternative agents for the control of introduced plants: Naturalized insects are those not native to this country but were accidentally released along with the host plant and 
have been in the country for such an extended period that they are now considered part of the ecosystem. The Asian hydrilla moth, (Parapoynx diminutalis Snellen), known from Pakistan to Southeast Asia (Delfosse et al. 1976), is considered to be a naturalized species in the U.S. It was found in Pakistan in 1973 and was considered to be a potential biocontrol agent for hydrilla in the U.S. (Buckingham and Bennett 1989, Balciunas et al. 2002). In 1976, however, it was reported feeding on hydrilla in south Florida, spreading rapidly causing extensive damage to the plants (Delfosse et al. 1976, Balciunas and Habeck 1981, Balciunas et al. 2002). It was likely introduced into the state through the aquarium industry (Balciunas et al. 2002), and could potentially be reared in large numbers to be used as a hydrilla biocontrol agent. In addition, the prime insect biocontrol agent for giant salvinia (Salvinia molesta D. S. Mitchell), the salvinia weevil (Cyrtobagous salviniae Calder and Sands), has been naturalized in the U.S. on common salvinia (Salvinia minima Baker) for years (Center et al. 1999) and offers potential for the control of both species in many areas of the country.

2. Develop native insect herbivores for use as biocontrol agents of native plants: For example, water-primrose (Ludwigia grandiflora (Michaux) Zardini, Gu, and Raven), although native to North and South America, is considered to be a nuisance plant in most of its range (Balsbaugh and Hays 1972, Aurand 1982, Chester and Hold 1990, MoGregor et al. 1996). The water-primrose flea beetle (Altica ludoviciana (Fall)) (syn. Lysathia ludoviciana (Fall)) is a natural enemy of water-primrose and can devastate stands of primrose if present in sufficient quantities. This insect would be a prime candidate as a potential biocontrol agent once more information is obtained concerning host specificity, biology, and the ability for massrearing. Another potential candidate for water-primrose management includes the native water-primrose leaf weevil (Perigaster cretura (Herbst)).

3. Understand the role native herbivores have on native plant growth, reproduction, etc.: It has been documented that one reason native plants can not effectively compete with introduced species such as hydrilla and EWM is that there is a lange assemblage of native herbivores and pathogens attacking the native species that significantly slows their growth and reproduction (Berg 1949, Wiggins 1977, Carpenter and Lodge 1986, Newman 1991, Cronin et al. 1998). Recent studies have shown that hydrilla invasions and subsequent expansions can be slowed significantly if native plants are well established in the area (Smart 1992, Smart 1993, Smart et al. 1994). In addition, the combined use of native plantings coupled with the release of the hydrilla leaf-mining flies can provide even better control 
than either method used alone (Grodowitz et al. 2007). Since plant competition is an important component for success when using hydrilla biocontrol agents, it is important to understand the whole range of biological factors that are impacting native plant species, especially the role of native herbivores and pathogens.

4. Understand native herbivores ecology, biology, host-specificity, and mass-rearing, to aid other countries with emerging plant problems: Many U.S. native plants have been transported to other countries and are now becoming invasive, including fanwort (Cabomba caroliniana Gray) in Australia (Mackey and Swarbrick 1997, Ensbey 2000, Schooler et al. 2005), coontail (Ceratophyllum demersum L.) in New Zealand (Wells et al. 1997, ISSG Global Invasive Species Database 2006), and pennywort (Hydrocotyle ranunculoides L. f.) in England (English Nature 1999, Newman and Dawson 1999, Newman 2004). By understanding the native herbivores of fanwort (or of any U.S. native plants that have become problems in other countries), one could aid them in finding and developing biological agents for these nuisance plants.

Information is presented herein concerning examples of native and naturalized agents that may potentially be used to impact and manage all types of aquatic and wetland plant species including introduced, naturalized, and native species. Information for each species includes a brief description, introduction history (if applicable), scientific, nomenclature and common name (if available), photographs (if available), general information and life history, biology, host-specificity, and operational status including research needed before deciding on the organism's usefulness. The amount of information for each organism varies because some have been studied extensively while only limited information exists for others. 


\section{Native and Naturalized Insect Herbivores and Fungal Pathogens of Aquatic and Wetland Plants}

Information is presented herein for selected native and naturalized agents that may potentially be used to impact and manage all types of aquatic and wetland plant species including introduced, naturalized, and native species. Native and naturalized insect herbivores and fungal pathogens discussed include: Acanthoscelides quadridentatus, Acentria ephemerella, Altica spp., Cyrotobagous salviniae, Donacia spp., Euhrychiopsis lecontei, Hydrellia bilobifera Cresson, $H$. discursa Deonier, Mycoleptodiscus terrestris, Ostrinia penitalis, Parapoynx diminutalis, Pergaster cretura, Simyra henrici, and Synclita oblieralis. 


\section{Acanthoscelides quadridentatus (Schaeffer) - Mimosa Seed Beetle (Coleoptera: Bruchidae) (Figure 1)}
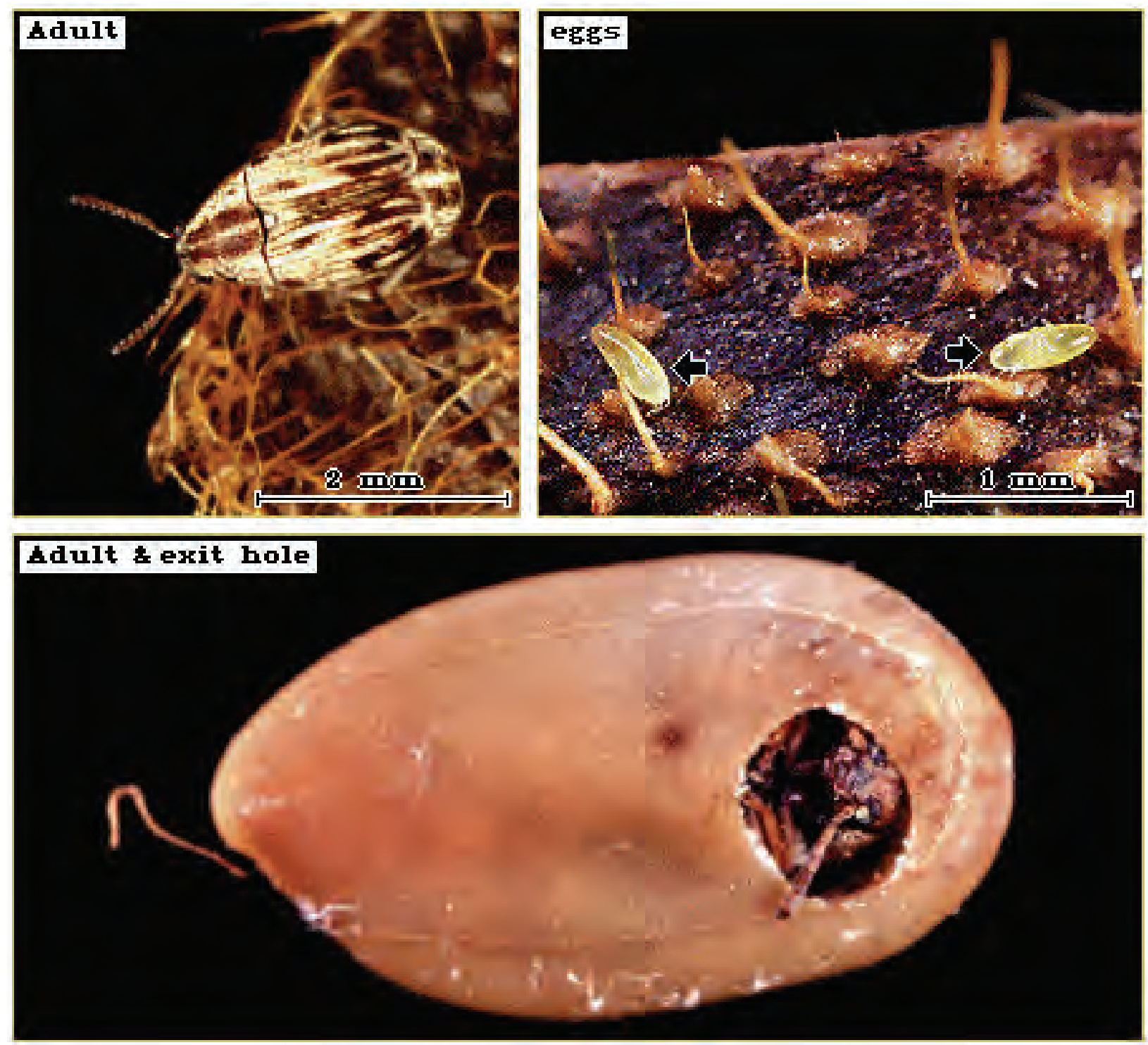

Figure 1. Mimosa seed beetle adult, eggs, and adult appearing in an exit hole.

(Photographs courtesy of the ERDC, 2005, APIS.)

\section{General Information and History}

The Mimosa seed beetle's (Acanthoscelides quadridentatus (Schaeffer)) distribution includes Texas, Mexico, Guatemala, Belize, Honduras, El Salvador, Nicaragua, Costa Rica, Panama, and South America (J ohnson 1983). Catclaw mimosa or giant sensitive plant (Mimosa pigra L. (Fabaceae)) was possibly introduced into Florida as early as 1926 (Fairchild 1944). The extensive canals and wetlands of southern Florida are similar to the habitats that have been invaded by catclaw mimosa elsewhere 
(McCann et al. 1996). In 1990, Schardt and Schmitz reported the plant was spreading rapidly and believed the species might rival melaleuca's ability to invade the Everglades. The high reproductive potential of catclaw mimosa and the persistence of its seeds in the soil account for its weedy nature (Lonsdale et al. 1988). Seed banks in Australia can contain 12,000 seeds $/ \mathrm{m}^{2}$, two orders of magnitude higher than in Mexico, which is within its native range (Lonsdale et al. 1988). This led the Australians to consider the introduction of seed predators (Harley 1985). Two bruchid species, A. quadridentatus (Schaeffer) and A. puniceus (Johnson), were released in 1983 (Kassulke et al. 1990).

\section{Biology}

The adults are small, brownish beetles (Figure 1 - Adult). The females lay their eggs on mature seed pods (Figure 1- Eggs) and upon hatching, the larvae bore into the seeds to complete their development (U.S. Army Engineer Research and Development Center (ERDC) 2005 Aquatic Plant Information System (APIS)). Each larva develops within a single seed (Center et al. 1999). Larval feeding causes the seed to become completely hollowed out which makes it nonviable (Center et al. 1999). Once the larvae finish development and pupate, the adults emerge through little round holes cut in the seed (Figure 1- Adult and exit hole) (Borror et al. 1976).

\section{Host-Specificity}

There have been no studies describing the impacts of this insect on its host plants (Center et al. 1999).

\section{Research/Impact}

According to Center and Kipker (1991), research/surveys were conducted during 1986 by biologists from the Florida Department of Natural Resources. Catclaw mimosa seeds were collected at infested Florida sites. Beetles later emerged from some of the seeds including those collected $10 \mathrm{~J} \mathrm{uly} 1986$ at a pepper farm located $10 \mathrm{~km}$ west of J upiter (Martin County) and were positively identified as A. quadridentatus. Seeds were later collected at the same site on several dates between J une and December 1989 to verify this record. Once again, A. quadridentatus emerged from some of the seeds; however, these bruchids destroyed only a small portion of the seed crop during this period (average < 1 percent, maximum 4.4 percent). Apparently adults could remain within hollowed-out seeds 
for extended periods. The site was going to be monitored further to determine if infestation rates varied seasonally. Unfortunately, the plants were destroyed by herbicide treatment. Samples were also collected in Saint Lucie County at two sites, the St. Lucie River and the C-23 canal, in 1989 but no bruchids emerged from the seeds.

\section{Possible Use in Control Programs}

Acanthoscelides quadridentatus could potentially be a useful biocontrol agent and would reduce seed quantities of catclaw mimosa if the insects were allowed to reach high enough population levels. However, this species makes up less than 3 percent of the beetles reared from field-collected catclaw mimosa seeds and, therefore, is unlikely to have any major effect on the plant populations, especially where seed production is very seasonal (J ulien and Griffiths 1999). More information is needed describing factors that are limiting their increase in the U.S. and the potential for development of mass-rearing and introduction programs.

\section{Acentria ephemerella Denis and Schiffermuller (syn: Acentria nivea Oliver) - Milfoil Moth, Water Veneer Moth (Lepidoptera: Pyralidae) (Figure 2)}
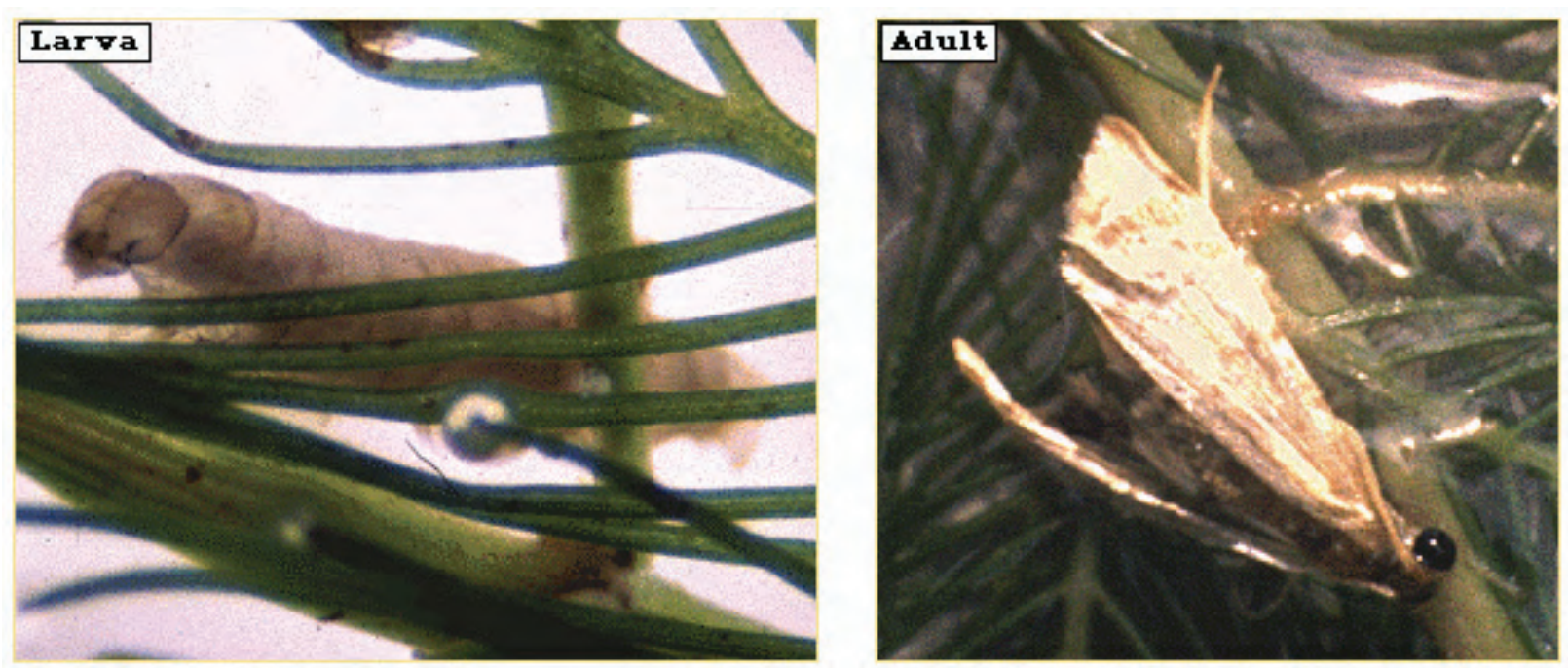

Figure 2. Milfoil moth larva and adult. (Photographs courtesy of the ERDC, 2005, APIS.)

\section{General Information and History}

Acentria ephemerella Denis and Schiffermuller, is an aquatic moth from Europe that was first reported in North America near Montreal in 1927 (Sheppard 1945). It is believed that this species was accidentally 
introduced to North America through the shipping trade (VanDusen 2003). Today this moth can be found from Massachusetts to Iowa and has been associated with declines of EWM, in Ontario, Canada, and New York (J ohnson and Blossey 2002).

\section{Biology}

The milfoil moth is one of the few moth species that completes almost its entire life cycle underwater (VanDusen 2003). Females lay their eggs near the bottom of EWM plants and after they hatch, the larvae crawl up the plant to feed on growing tips (Figure 2 - Larva) (Northern New York Agricultural Program 1999). The larvae move about the plant eating the tips as they complete their five instar stages (Northern New York Agricultural Program 1999). The males emerge from the water for a brief day or two to conduct a courtship flight (Figure 2 - Adult). Most females are wingless and float on the surface of the water waiting to attract a mate (VanDusen 2003). Once the females have mated, they dive down into the water to lay their clutch of eggs, which ranges from 100 to 300 eggs per clutch. Winged females usually lay less than 100 eggs per clutch (VanDusen 2003).

\section{Host-Specificity}

In initial host-specificity tests conducted in the 1970's, milfoil moth larvae fed on almost all test plants offered to them, which reduced interest in use of this insect as a potential biocontrol agent for EWM (Buckingham and Ross 1981). Recent declines of EWM associated with the milfoil moth, however, have caused a reevaluation of the usefulness of this insect as a potential biological control agent (J ohnson and Blossey 2002).

\section{Research/Impact}

A twelve-year study conducted at Cayuga Lake, New York, looked at aquatic plant biomass and showed a dramatic decline of EWM associated with large populations of the milfoil moth (J ohnson et al. 1998, Gross et al. 2001). In the summer of 1997, a five-lake survey in New York was conducted to explore the relationship between lake size, abundance of EWM, and EWM herbivore numbers (J ohnson et al. 2000). Data were collected from five lakes (Cayuga, Dryden, Keuka, Lamoka, and Waneta). Observations from the five-lake survey concluded that milfoil moth densities have a highly significantly negative correlation with percentage composition 
and total dry mass of EWM (J ohnson et al. 2000). Also, the decline of EWM associated with the milfoil moth in Cayugua Lake suggests that this insect may be an effective long-term biological control agent (J ohnson et al. 2000).

\section{Possible Use in Control Programs}

In some areas of New York, the mass production of the milfoil moth and procedures for its release and evaluation have been undertaken (Hairston and J ohnson 2001), but more work is needed.

\section{Altica spp. - Flea Beetles; Leaf-Feeding Beetles; Water-Primrose Flea Beetle (Coleoptera: Chrysomelidae: Halticinae) (Figures 3-5)}
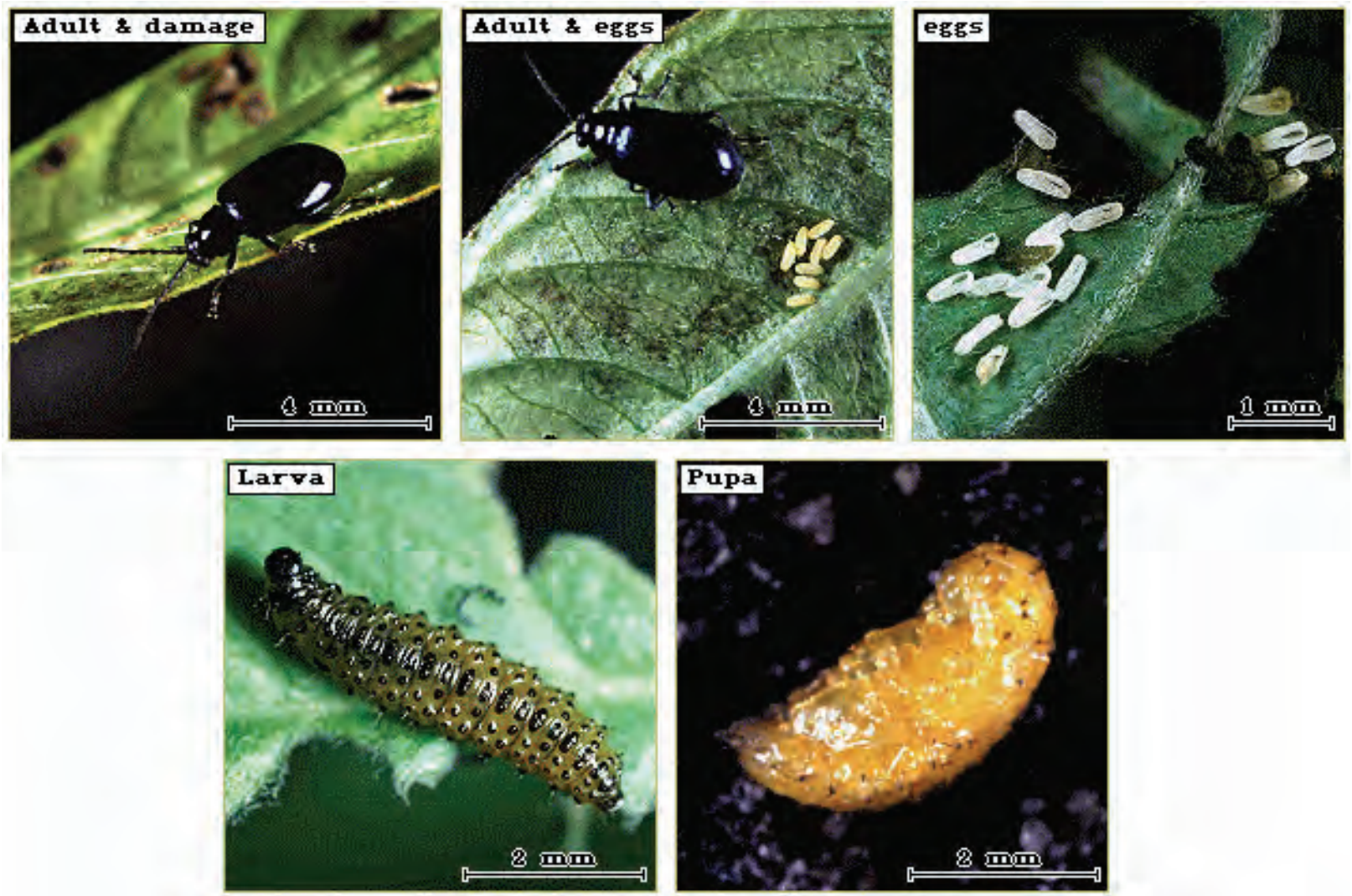

Figure 3. Altica litigata Fall - Water-Primrose Flea Beetle adult damage, adult and eggs, eggs, larva, and pupa. (Photographs courtesy of the ERDC, 2005, APIS.) 

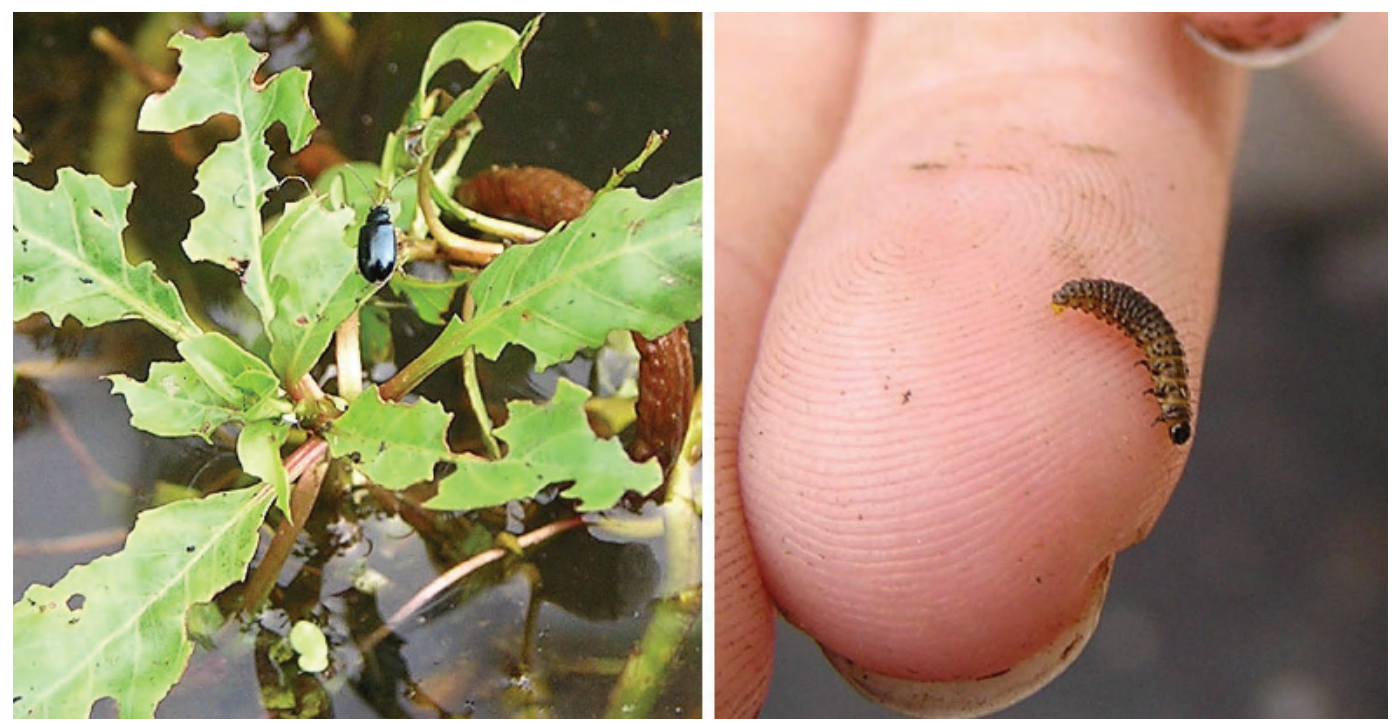

Figure 4. Water-primrose flea beetle adult and larvae. (Photographs courtesy of Dr. Michael J. Grodowitz, ERDC, September 2004.)

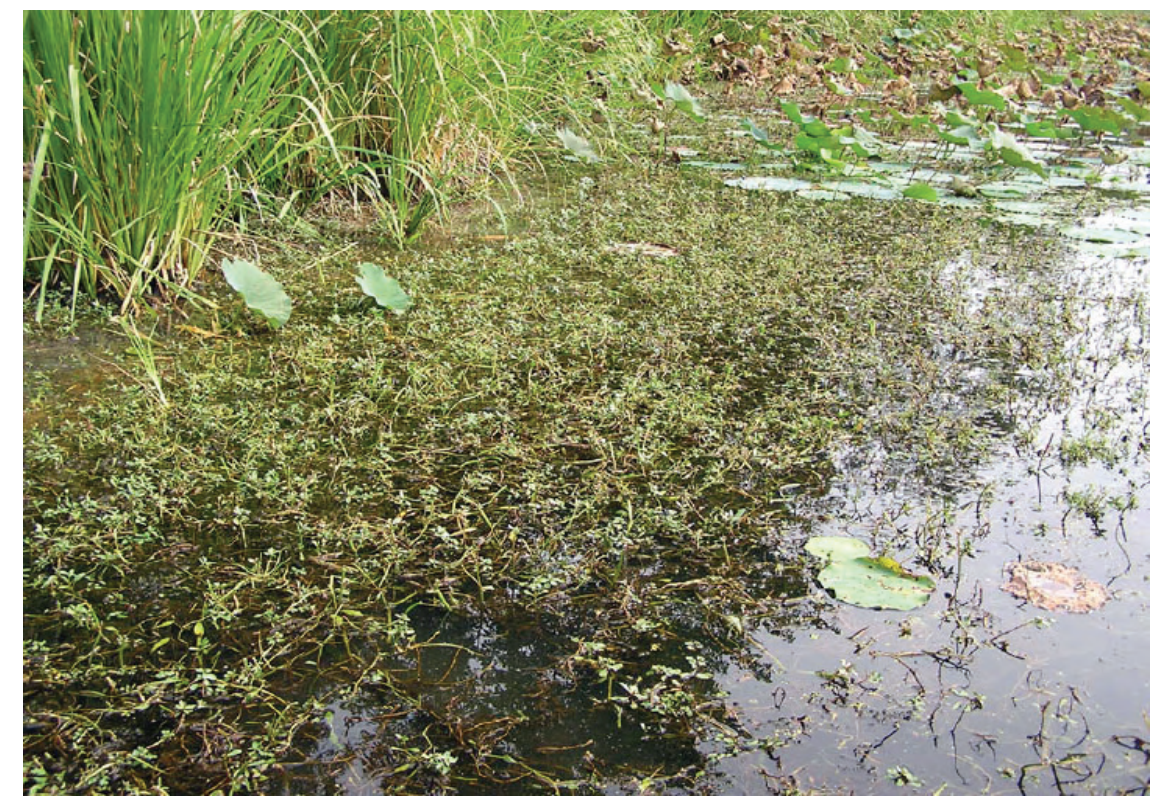

Figure 5. Primrose damaged by water-primrose flea beetle.

(Photograph courtesy of Dr. Michael J. Grodowitz, ERDC, September 2004.)

\section{General Information and History}

Flea beetles are small jumping leaf beetles that have enlarged hind femora (Borror et al. 1976). Most of them are blue or greenish, but many are black or black with light markings (Borror et al. 1976). Many of them are important pests of garden and field crops, but several have been studied as potential biocontrol agents of nuisance plants. Water-primrose (Ludwigia spp.), although native to North and South America, has been considered a 
nuisance plant in most of its range (Balsbaugh and Hays 1972, Aurand 1982, Chester and Hold 1990, McGregor et al. 1996). The natural hosts of the water-primrose flea beetle (Altica ludoviciana (Fall)) (syn. Lysathia ludoviciana (Fall)) include water-primrose, parrotfeather (Myriophyllum aquaticum (Velloso) Verde) (Habeck and Wilkerson 1980, Washington State Department of Ecology 2003), and creeping water primrose (L. peploides (H.B.K.) Raven) (McGregor et al. 1996).

The water-primrose flea beetle has also been studied at Auburn University in Alabama as a potential biological control of Uruguay waterprimrose $(L$. uruguayensis (Camb.) Hara) (MoGregor et al. 1996; USDA, NRCS 1999). The water-primrose flea beetle (Altica litigata Fall) has been found to feed on another water-primrose (L. octovalvis (J acq.) Raven), waterpurslane (L. palustris (L.) Ell.) (Center et al. 1999), and purple loosestrife (Lythrum salicaria L.), an invasive, exotic, wetland plant that replaces native species and clogs waterways (Hoyme et al. 2001). Altica foeveicollis J acoby, an endemic species of flea beetle in Thailand, has been a very effective natural control of the water-primrose (L. adscendens L. Hara) and other Ludwigia spp. in Thailand (Napompeth 1994, J ulien and Griffiths 1999). At the Department of Zoology, Burdwan University, India, Nayek and Banerjee (1987) are testing Altica cyanea as a potential biological control agent. The country of Malaysia is particularly interested in using this beetle to help control $L$. adscendens growing as a weed in rice-paddies (Nayek and Banerjee 1987).

\section{Biology}

Altica litigata Fall adults are shiny metallic green, ca. $4 \mathrm{~mm}$ in length (Figure 3 - Adult and damage, adult, and eggs). Female $A$. litigata lay yellowish, oblong eggs in groups on the leaf surface (Figure 3 - Adult and eggs, eggs). The larvae have a greenish-yellow body with a black head capsule and distinctive black plates on their bodies (Figure 3 - Larva) (Center et al. 1999). The larvae burrow into the soil to pupate (ERDC, 2005, APIS). The yellow pupa are found close to the soil surface in a loosely constructed chamber (Figure 3 - Pupa) (ERDC, 2005, APIS). Larvae and adults feed on the leaves of plants causing irregular holes in the foliage followed by foliar scraping by the larvae (Schultz et al. 2001). Altica ludoviciana are ca. 4-5 $\mathrm{mm}$ in length, and are dark brown with a bluish-black appearance. They are differentiated from other beetles by their greatly enlarged hind femora (McGregor et al. 1996) and their enlarged yellowishbrown legs (Habeck and Wilkerson 1980). Flea beetle feeding by both lar- 
vae and adults causes skeletonizing of the foliage and eventual leaf drop (Figures 4 and 5) (Schultz et al. 2001).

\section{Research/Impact}

A two-year study initiated in 2000 by the University of Tennessee, Department of Entomology and Plant Pathology, Knoxville, TN, assessed the impact of $A$. litigata on leaf consumption and seed production of purple loosestrife in eastern Tennessee (Hoyme et al. 2001). The researchers found that larval feeding was extensive and caused the foliage to appear skeletonized, thus reducing seed production and the number of seeds per capsule.

\section{Possible Use in Control Programs}

Two Altica spp. have shown potential for use in aquatic weed management programs, A. litigata on purple loosestrife, and A. ludoviciana on L. uruguayensis. Hoyme et al. (2001) witnessed a large population of $A$. litigata feeding on purple loosestrife greatly impacting the plant's production of seed capsules and seeds. From this positive activity, Hoyme et al. (2001) felt that $A$. litigata would prove to be a potential agent for purple loosestrife. Researchers at Auburn University Fisheries Research Field Station, Auburn, AL (1996), have studied the effects of A. ludoviciana on

L. uruguayensis. Changes in aquatic macrophyte communities and insect abundance in six littoral enclosures ( 5 x $10 \mathrm{~m}$ ) where a population of L. uruguayensis had been colonized by A. ludoviciana were quantified (McGregor et al. 1996). Water primrose dry weight biomass declined during the four sampling times taken from J uly to September. The flea beetles were sampled nine times between J uly and October, and although the abundance was variable there were three peaks in abundance on 15J uly, 5 August, and 30 September. In the spring of 1995, no beetles were found within the enclosures (McGregor et al. 1996). More research is needed on Altica spp. taxonomy, biology, seasonality, and host-specificity. Coinciding with this basic work is the need to develop efficient massrearing procedures. 


\section{Cyrtobagous salviniae Calder and Sands, Salvinia Weevil (Coleoptera:} Curculionide: Curculioninae: Erirhinini) (Figure 6)
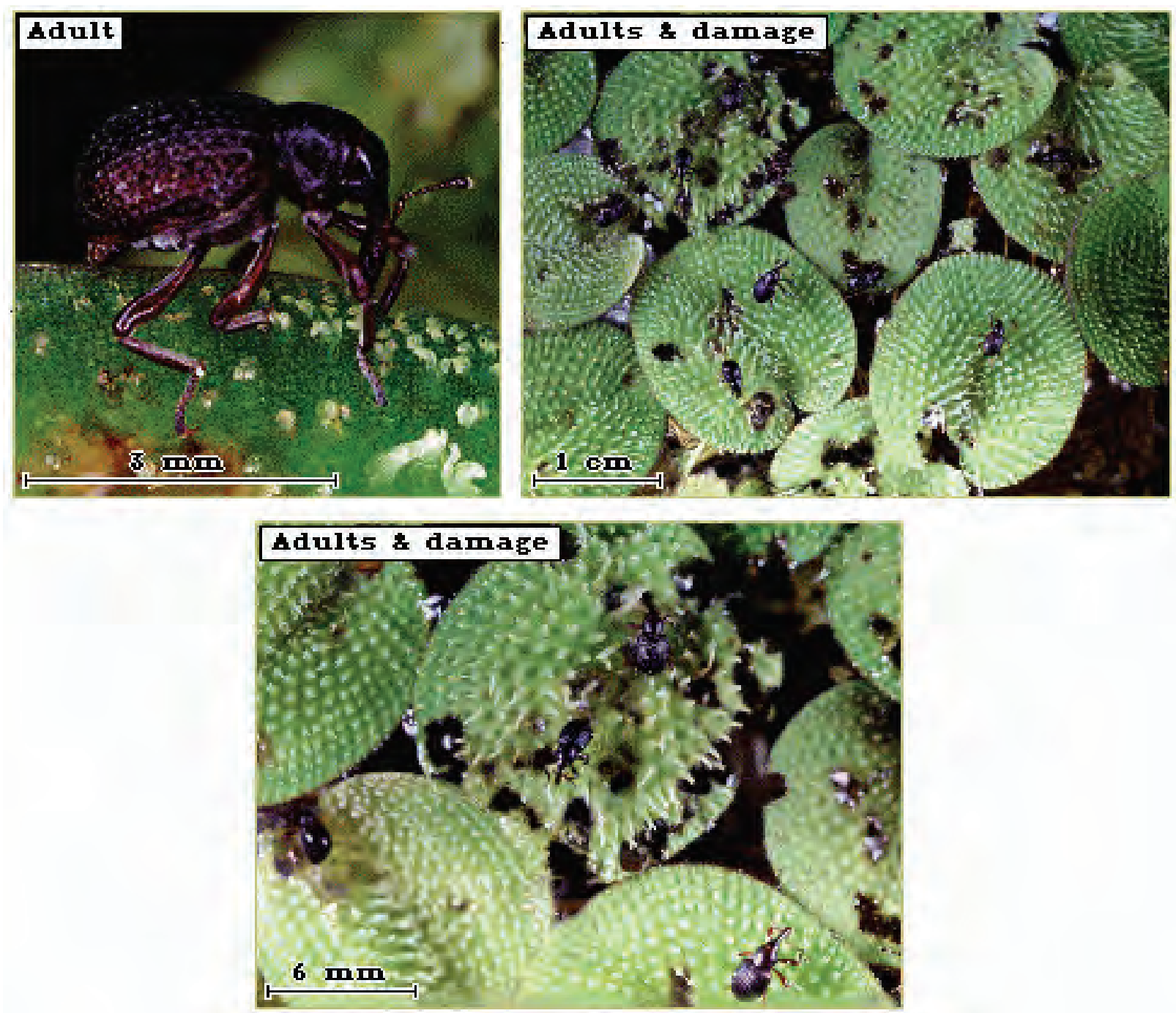

Figure 6. Salvinia weevil adults and damage. (Photographs courtesy of the ERDC, 2005, APIS.)

\section{General Information and History}

The salvinia weevil (Cyrtobagous salviniae Calder and Sands) was first discovered in the United States at the Archbold Biological Station, Highlands County, Florida in 1962 (Center et al. 1999). Due to the lack of U.S. records, it was assumed that the weevils were accidentally introduced from South America. The salvinia weevil feeds on the nuisance, floating ferns, giant salvinia (Salvinia molesta D.S. Mitchell), and common salvinia (S. minima Baker), and has been used successfully as a biocontrol agent in India, Africa, Sri Lanka, Southeast Asia, Papau New Guinea, and Australia, 
dramatically reducing large infestations of Salvinia (Center et al. 1999, Julien and Griffiths 1999).

\section{Biology}

Salvinia weevils are small and generally reside on the underside of Salvinia fronds (ERDC, 2005, APIS, J ulien et al. 2002) (Figure 6 - Adult). The average size of the males is $1.8 \times 0.9 \mathrm{~mm}$, which is slightly smaller than the females ( $2.2 \times 1.2 \mathrm{~mm}$ ) (J ulien et al. 2002). Newly emerged weevils are brown in color darkening to black after about five days (J ulien et al. 2002). The females lay single eggs in the floating leaves of giant Salvinia (Center et al. 1999). Eggs hatch in about 10 days. The larvae are white and approximately $3 \mathrm{~mm}$ in length (Center et al. 1999). One important characteristic of $C$. salviniae that distinguishes it from another Cyrtobagous weevil, $C$. singularis Hustache, is its larval feeding habit. The larvae of $C$. salviniae tunnel into the rhizomes of Salvinia causing them to disintegrate, while the adults feed on the buds, suppressing plant growth (Center et al. 1999). The larvae and adults of $C$. singularis only feed on leaves and other tissues and not on the actively growing rhizomes or meristems, making it an ineffective biocontrol agent. Distinguishing between the two species is essential to insure successful biological control (Center et al. 1999).

\section{Host-Specificity}

In South America, Forno et al. (1983) observed C. salviniae (at that time thought to be $C$. singularis) attacking Salvinia spp. and not feeding on plants that grow in association with it (waterfern (Azolla spp.), waterhyacinth (Eichhornia crassipes [Mart.] Solms-Lauback), and waterlettuce (Pistia stratiotes L.)). This weevil was later found to be a new species and was subsequently described as C. salviniae Calder and Sands (J ulien et al. 2002). In Australia host range tests were conducted with C. salviniae on 46 species of plants - six families of Pteridophyta (ferns), eleven families of Monocotyledons, and sixteen families of Dicotyledons (Forno et al. 1983). Adult feeding occurred on waterlettuce, but the insect could not reproduce on the plant. It also fed on sweet potato (Ipomea batatas (L.) Lam.) when this plant was held in contact with water, but when grown in its normal, non-aquatic situation, the weevils failed to feed on it. The conclusion of the host-specificity tests was that $C$. salviniae was restricted to feeding on Salvinia spp. Even when huge populations of weevils were starving once 
the Salvinia spp. had crashed, they were not found attacking other plant species (J ulien et al. 2002).

\section{Research/Impact}

The feeding action of both the adults (Figue 6 - Adults and damage) and larvae can have a devastating effect on field populations of Salvinia spp. Results of the feeding damage appear in months rather that in years, which is the usual action of other biocontrol agents (ERDC, 2005, APIS). The initial damage appears as a browning of the plants, which spreads out until almost the entire mat is brown and damaged. Once the damage is widespread and the plants are sufficiently damaged, the mat begins to sink (ERDC, 2005, APIS).

\section{Possible Use in Control Programs}

In 1999 C. salviniae collected from common salvinia in Florida by scientists from the USDA, ARS, Invasive Plant Research Laboratory were released at several sites in Texas and one site in Louisiana, but establishment was unsuccessful (Julien et al. 2002, ERDC, 2005, APIS).

Leeda A. Wood and Daniel Flores, both entomologists with the United States Department of Agriculture (USDA), Center for Plant Health Science and Technology, Plant Protection and Quarantine, Animal and Plant Health Inspection Service, Pest Detection, Diagnostics and Management Laboratory, 22675 N. Moorefield Rd., Moore Air Base Bldg. 6414, Edinburg, TX 78541-9398, are currently working on ways to develop biological control strategies for giant salvinia in East Texas using C. salviniae. They are documenting the distribution of giant salvinia and the extent of infestations in waterways in East Texas. In addition they are examining dispersal techniques for C. salviniae, evaluating previous field releases in East Texas, evaluating previously used methods for controlling giant salvinia in East Texas, documenting the impact of $C$. salviniae on nontarget species, and transferring this technology to other agencies for managing giant salvinia. These two USDA scientists have been in contact with personnel at the Lewisville Aquatic Ecosystem Research Facility (LAERF), in Lewisville, TX, a research facility that is part of ERDC, to help them develop mass-rearing techniques for $C$. salviniae.

In May 2004, four ponds of giant salvinia were set up at LAERF for a mass-rearing experiment of the salvinia weevil. The pond experiment 
(Figure 7 - A, B, C, and D) was designed to examine the effects of fertilized giant salvinia on the establishment of $C$. salviniae: Pond A - fertilized every two weeks with $100 \mathrm{lb}$ ammonium sulfate; Pond B - fertilized every two weeks with $40 \mathrm{lb}$ ammonium sulfate; Pond C - fertilized every 2 weeks with $10 \mathrm{lb}$ ammonium sulfate; and Pond D - not fertilized. According to LAERF personnel, the ponds with the higher nitrogen rate had more and larger brown areas of giant salvinia (i.e. more insect damage) (conversation with LAERF personnel, November 2004).



Figure 7. C. salviniae released in four ponds at LAERF - May 2004. Photograghs taken four months after release: (Pond A) $100 \mathrm{lb}$ ammonium sulfate every 2 weeks, (Pond B) $40 \mathrm{lb}$ ammonium sulfate every 2 weeks, (Pond C) $10 \mathrm{lb}$ ammonium sulfate every 2 weeks, and (Pond D) not fertilized. (Photos courtesy of LAERF personnel.)

More efficient and less labor-intensive procedures are needed to mass-rear and release large numbers of the weevils. Also needed are better adult extraction methods so weevils can be released on both $S$. molesta and S. minima simultaneously. In addition, more efficient field evaluation methods are needed. 
Donacia spp., Long-Horned Leaf Beetles (Coleoptera: Chrysomelidae: Donaciinae) (Figures 8 and 9)
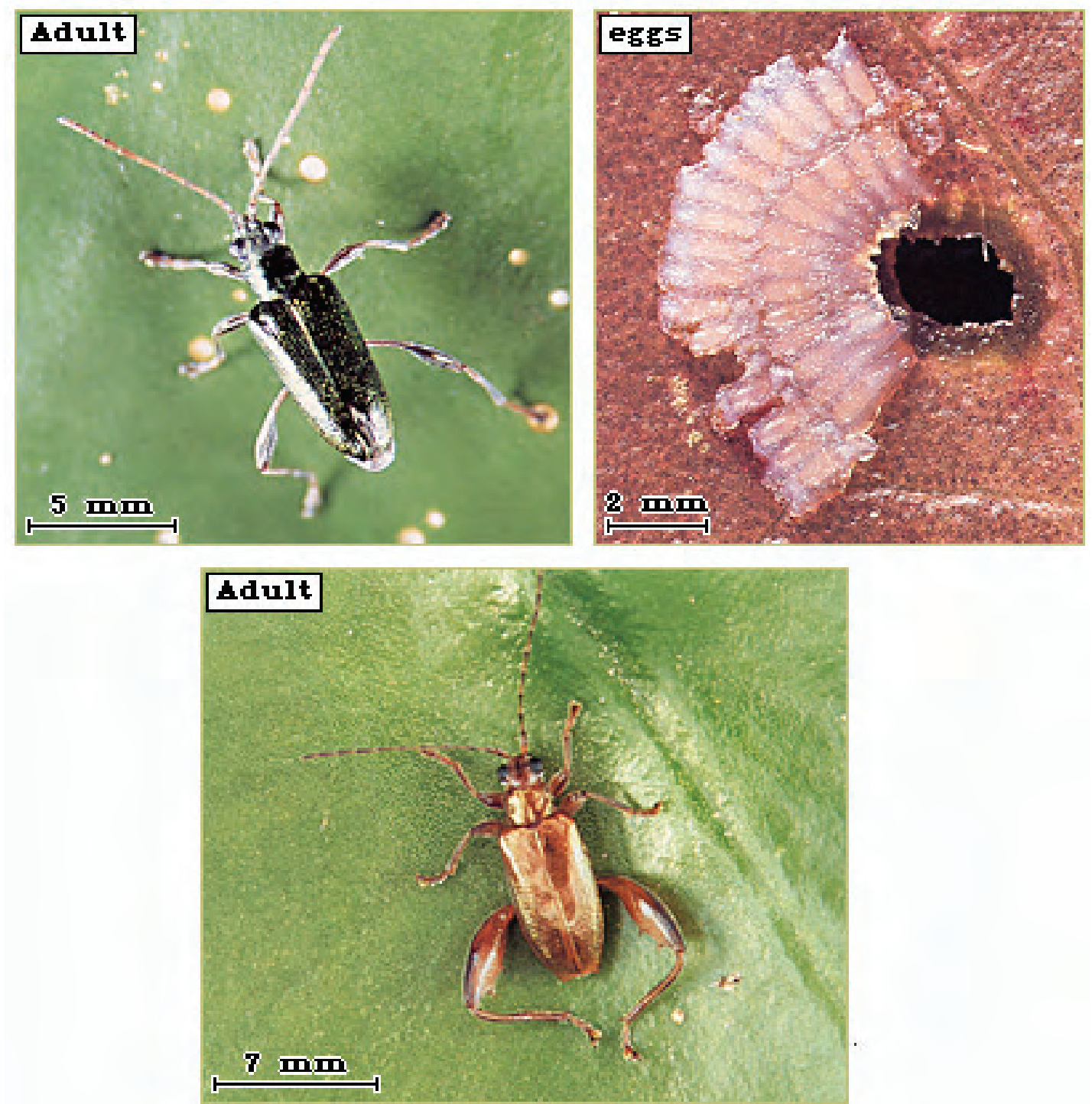

Figure 8. Eggs and adults of the long-horned leaf beetle.

(Photographs courtesy of the ERDC, 2005, APIS.) 


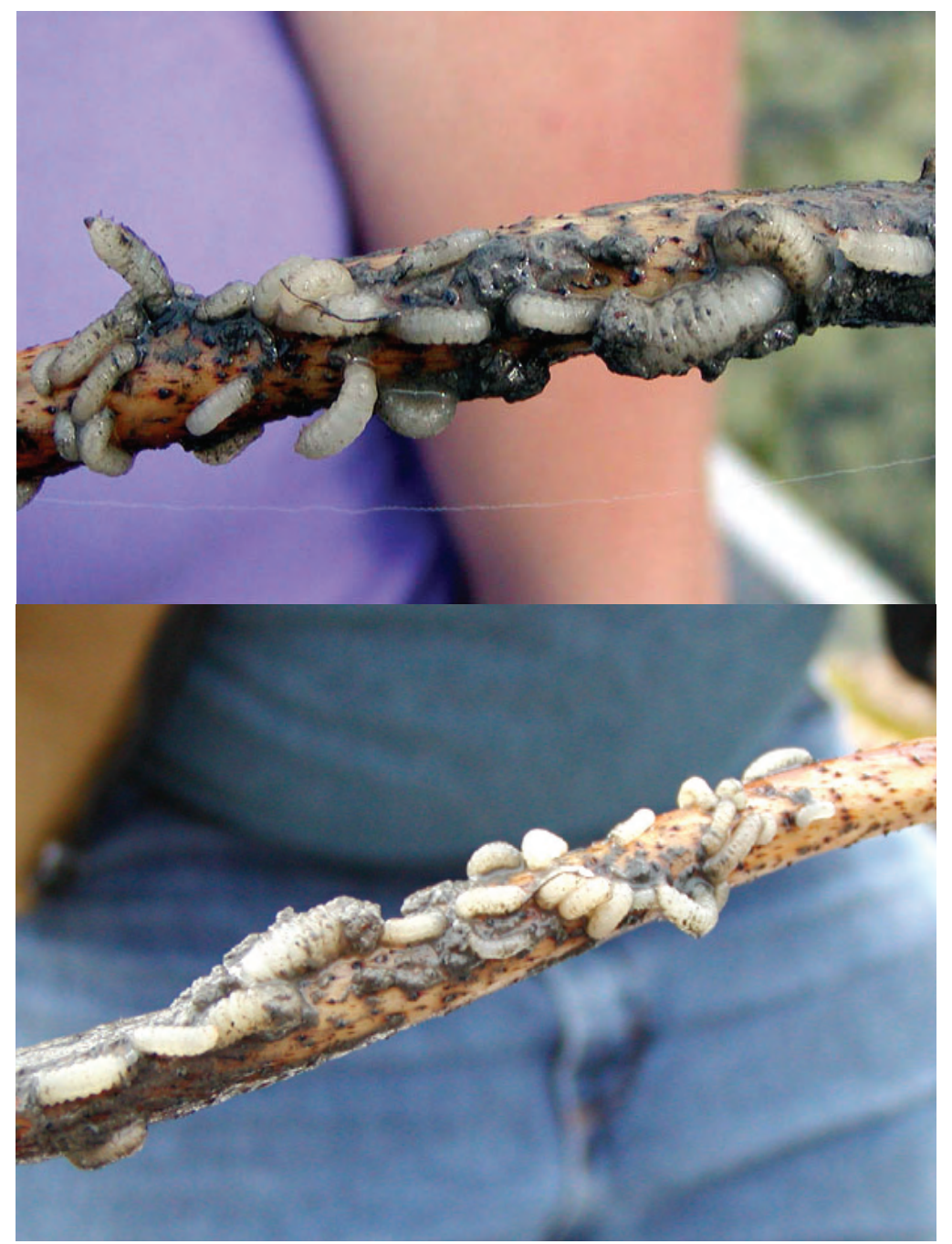

Figure 9. Long-horned leaf beetle larvae feeding on a stalk of American Lotus, Lake Cypress Springs, Texas - 2004. (Photographs courtesy of Dr. Michael J. Grodowitz, ERDC, and Julie G. Nachtrieb, LAERF.)

\section{General Information and History}

Donacia spp., the longhorned leaf beetles, belong to the largest group of aquatic Chrysomelids in North America (Center et al. 1999, ERDC, 2005, APIS). Despite being such a large group, few details are known about most of the species' life histories. Of the 31 Donacia species occurring in North America, most are found in the southeastern United States (Center et al. 1999).

\section{Biology}

Long-horned leaf beetles, as described by Borror et al. (1976), are seldom found far from water, and the adults are frequently located on the flowers 
or foliage of water lilies, pondweed, and other aquatic plants (Figure 8 Adults). Eggs are usually laid on the undersides of leaves of aquatic plants (Figure 8 - Eggs). The larvae feed on the submerged portions and obtain air through the plant stems (Figure 9). Pupation occurs in cocoons that are fastened to the submerged parts of the vegetation.

\section{Host-Specificity}

Long-horned leaf beetles feed on at least 50 aquatic plant species, including spatterdock (Nuphar lutea (L.) Sm.), waterlily (Nymphaea spp.), and American lotus (Nelumbo lutea (Willd.) Pers.) (ERDC, 2005, APIS). Unfortunately, very little species specific information is available.

\section{Research/Impact}

To date, no research has been conducted describing the impact of this insect on its host plants (Center et al. 1999), or its possible use in biocontrol programs. In 2004, Dr. Michael J . Grodowitz (ERDC) and J ulie G. Nachtrieb (LAERF) found Donacia spp. larvae covering the stalks of American lotus in Lake Cypress Springs, Texas. The larvae had degraded the plants to such a degree that the lotus could be pulled straight out of the lake's sediment with little or no effort. Despite being native, American lotus can sometimes become a nuisance plant. Bassett et al. (1993) warn that American lotus can grow so rapidly it can completely cover a 1-acre pond in 3 to 4 years and should never be introduced into most fishing ponds. Whetstone et al. (2000), Cooperative Extension specialists at Clemson University, caution in their publication "Home and Garden Information Center: Aquatic Plant Selection" that American lotus may be invasive. From the voracious feeding of Donacia spp. larvae on American lotus at Lake Cypress Springs, this insect could be viewed as a potential biocontrol agent in situations where American lotus has become invasive.

\section{Possible Use in Control Programs}

More research is needed in describing various species taxonomically and developing information on life history, biology, host-specificity, and ecology. Once this information is obtained and individual species appear promising, mass-rearing techniques should be developed. 


\section{Euhrychiopsis lecontei (Dietz), Milfoil Weevil (Coleoptera:} Curculionidae) (Figures 10 and 11)
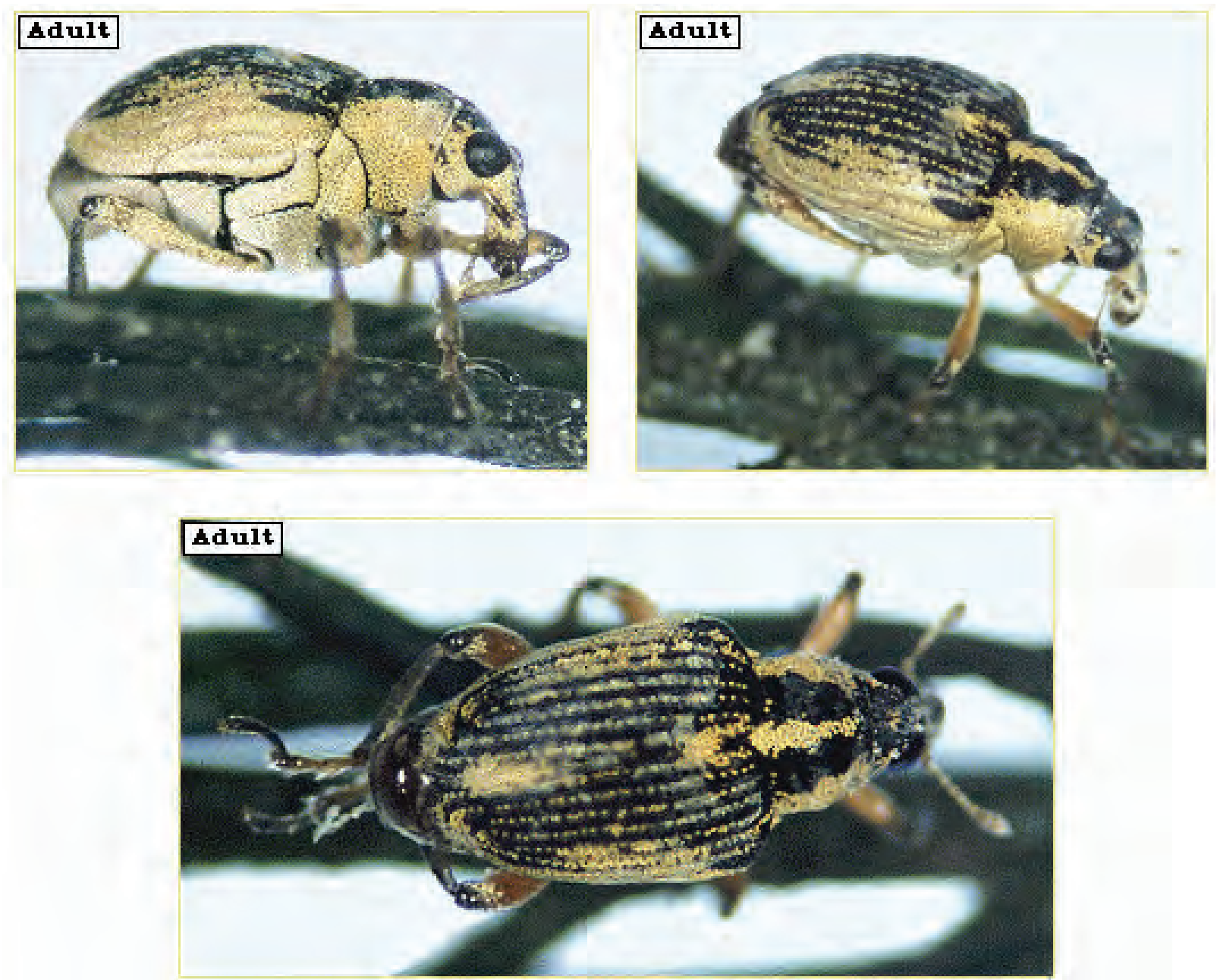

Figure 10. Milfoil weevil adults. (Photographs courtesy of the ERDC, 2005, APIS.) 


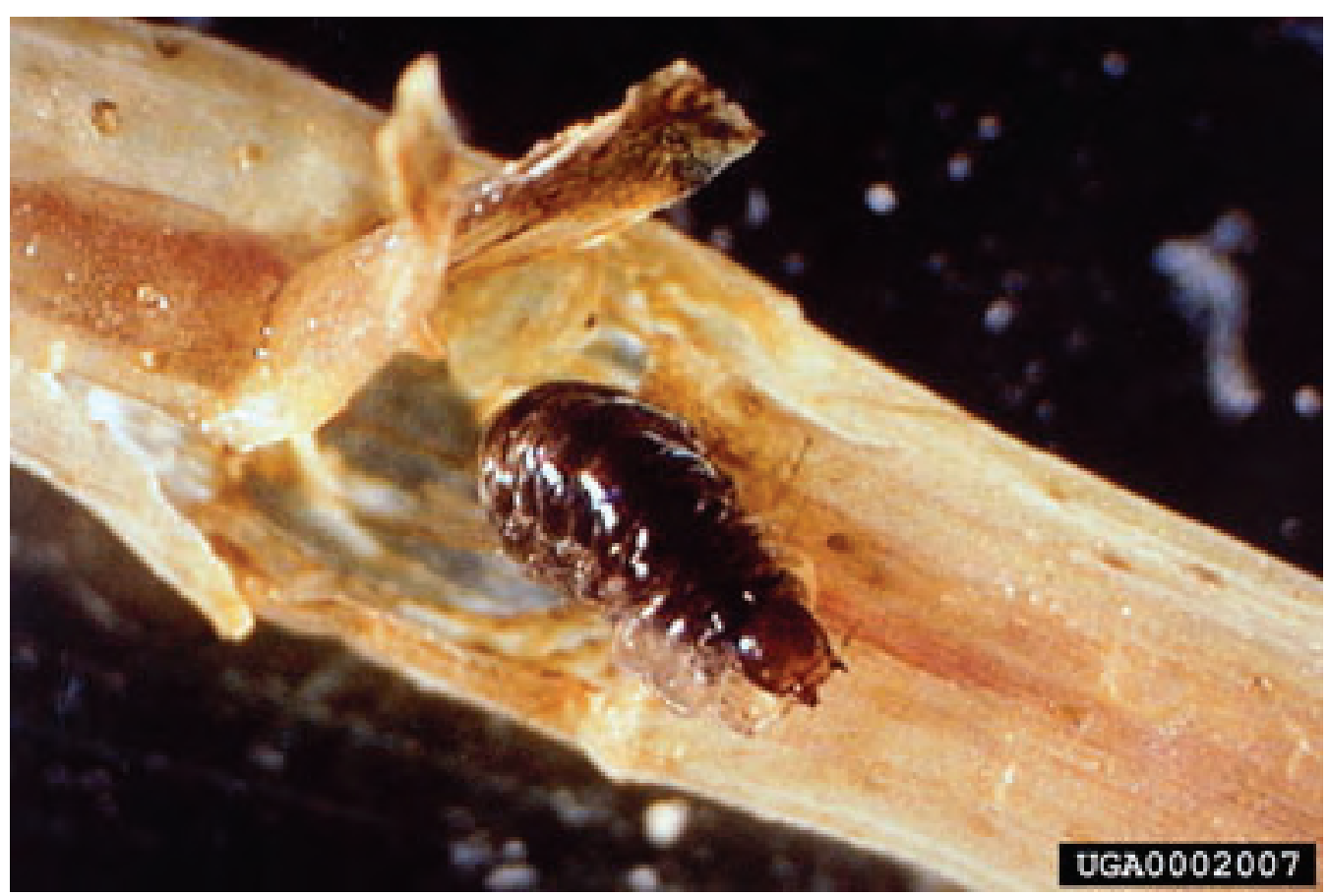

Figure 11. Milfoil weevil larva in stem nearing pupation. (Photograph by Robert L. Johnson, Cornell University, www.forestryimages.org, www.invasive.org/search.)

\section{General Information and History}

The submersed aquatic milfoil weevil (Euhrychiopsis lecontei Dietz), is a native North American species that traditionally feeds on northern watermilfoil (Myriophyllum sibiricum Komarov) (J ohnson and Blossey 2002; Solarz and Newman 2001). After a EWM decline in Browning Pond, Vermont was linked to $E$. lecontei, surveys and research were conducted to determine whether this native weevil would be a viable insect biocontrol agent for EWM (Creed and Sheldon 1994b).

\section{Biology}

The weevils are small ( 2 to $3 \mathrm{~mm}$ in length), dark in color with brown and yellow markings on the upper half of the body (Grodowitz et al. 2007, Johnson and Blossey 2002) (Figure 10 - Adults), and feed on leaves and stems. After mating, the females lay an average of 1.9 eggs per day, about 200 total, producing one egg per EWM apical meristem (J ohnson and Blossey 2002). Adults and all larval stages of the milfoil weevil feed on EWM. First instar larvae burrow into the meristem feeding for 3 to 5 days whereas older larvae feed inside the stem causing extensive damage and holes (Figure 11) (ERDC, 2005, APIS). Adult weevils feed on the meristems, leaves, and stems of EWM. The result of adult and first instar larvae 
feeding can have a significant effect on the plant's grouth (Creed and Sheldon 1994b). The effect of later instar larvae feeding on the plants is more varied, but may influence EWM growth by destroying stem vascular tissue (Creed and Sheldon 1994b).

\section{Host-Specificity}

Host plants for E. lecontei include the exotic EWM and the native northern watermilfoil (Creed and Sheldon 1994a, Solarz and Newman 2001). The weevil oviposits and develops on both species of plant, but host plant preference was affected by which species of plant the weevils were collected or reared on. Weevils that were collected or reared on EWM preferred it, however insects collected or reared on northern watermilfoil, had an equal preference for both EWM and northern watermilfoil (Solarz and Newman 2001). In another experiment, weevil populations that had been exposed to both EWM and northern watermilfoil were used in a four-species oviposition experiment (Solarz and Newman 2001). The four watermilfoil species included two natives (northern milfoil and whorled watermilfoil (M. verticillatum L.) and two exotics (EWM and parrotfeather). From this experiment, both EWM and northern watermilfoil exposed weevils oviposited on all four watermilfoil species. The weevils exposed to EWM, however, had a higher preference for this plant while northern watermilfoil exposed weevils distributed their preferences fairly evenly for all four watermilfoil species (Solarz and Newman 2001).

The knowledge of hybridity between EWM and $M$. sibiricum has developed new questions about the effectiveness of $E$. lecontei, since hybrids often deter herbivory better than their parental species (Floate and Whitham 1994; Fritz et al. 1994; Whitham et al. 1999; Moody and Les 2002). A population of EWM growing in Lake Beulah, Wisconsin was considered to be resistant because it showed very little damage from the milfoil weevil, and no pupal development was seen on apical meristems (J ester et al. 2000). Upon examination and analysis of the plants, they were found to be hybrids, demonstrating that hybrid milfoils can show resistance to leaf-feeding weevils (Moody and Les 2002).

\section{Research/Impact}

Extensive research has been conducted on E. lecontei including: (1) developmental rates and damage to EWM at constant temperatures (Mazzei et al. 1999); (2) weevil-EWM interaction at different spatial scales (Creed 
2000); (3) temporal and spatial changes in EWM distribution and biomass associated with weevils in Fish Lake, WI (Lillie 2000); and (4) the relationship between water quality, watermilfoil frequency, and weevil distribution in the state of Washington (Tamayo et al. 2000). Creed and Sheldon (1994b) also conducted extensive studies to determine the effect E. lecontei had on EWM in pool and aquarium experiments.

Creed and Sheldon (1994b) determined that E. lecontei adults and first instar larvae could have a significant negative effect on EWM growth. Adults and first instar larvae feeding on milfoil meristems slowed the increase in plant length by preventing further apical growth. Adults feeding on leaves removed significant amounts of whole leaves and leaflets, severely affecting the energy balance of the plant. Herbivory on upper leaves also forced the plant to rely on deeper leaves for photosynthesis. Lesions created by adult feeding made the plants more susceptible to bacterial and fungal attacks. The combination of stem feeding by both adults and larvae caused the plants to lose buoyancy and eventually to sink.

Late instar larvae of $E$. lecontei influenced EWM growth by destroying stem vascular tissue (Creed and Sheldon 1994b). Removal of vascular tissue could reduce or halt the translocation of nutrients and sugars within the plants.

\section{Possible Use in Control Programs}

According to Creed and Sheldon (1994b), E. lecontei meets the criteria outlined by Harley and Forno (1992) for a successful classical biocontrol agent. Specifically it: (a) becomes a permanent part of the biota; (b) is self-regulating and self-perpetuating; and (c) provides acceptable control of the target plant, in this case, EWM. Euhrychiopsis lecontei is already a permanent member of the North American biota; survey data taken by Creed and Sheldon (1994b) at Brownington Pond, a 54-ha pond in northeastern Vermont, between 1986 and 1989, showed that the weevil is selfperpetuating and self-regulating. Brownington Pond originally had EWM beds covering 30 to 35 percent (10 - 11 ha) of the littoral zone. By 1989, only ca. 1.0 percent of the littoral zone was covered by EWM. Creed and Sheldon (1994b) both felt that, based on the results and observations of their studies, E. lecontei should be considered for use as a biological control agent for EWM in North America. More efficient mass-rearing and release strategies, coupled with additional information on field impact, is needed, however. 
Hydrilla Leaf-mining Flies, Hydrellia bilobifera Cresson, and $\boldsymbol{H}$. discursa Deonier (Diptera: Ephydridae: Notiphilinae: Hydrelliini) (Figures 12-15)

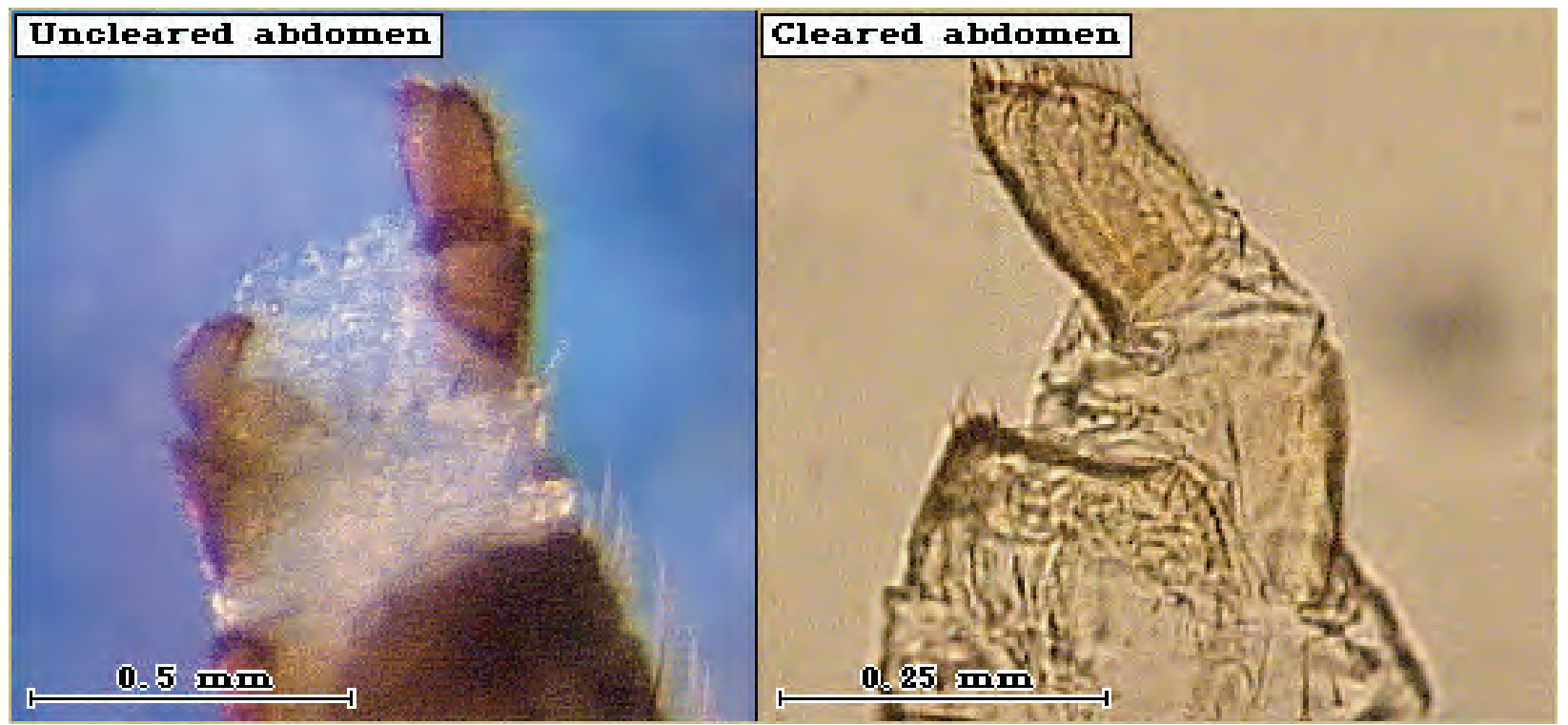

Figure 12. Female - Hydrellia bilobifera - cerci are long and narrow. (Photographs courtesy of the ERDC, 2005, APIS.)
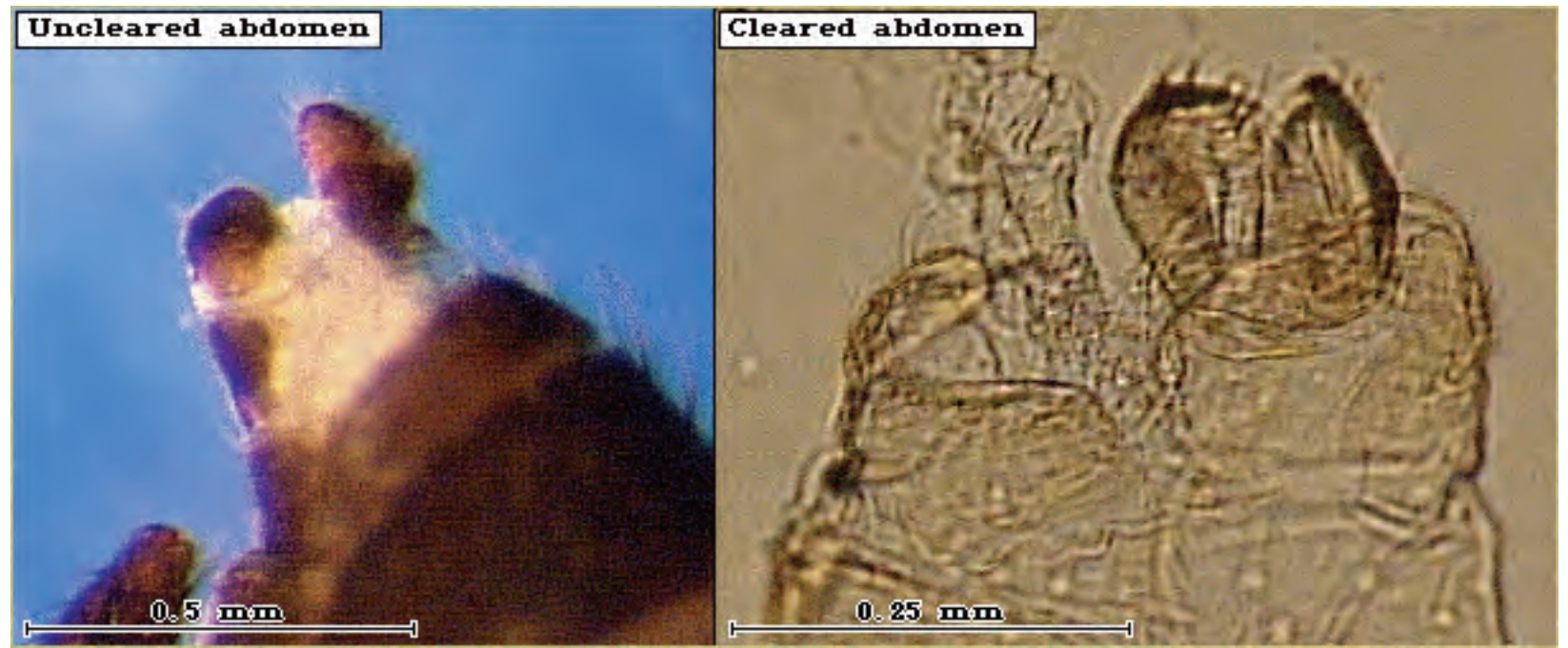

Figure 13. Female - Hydrellia discursa - cerci are short and round. (Photographs courtesy of the ERDC, 2005, APIS.) 


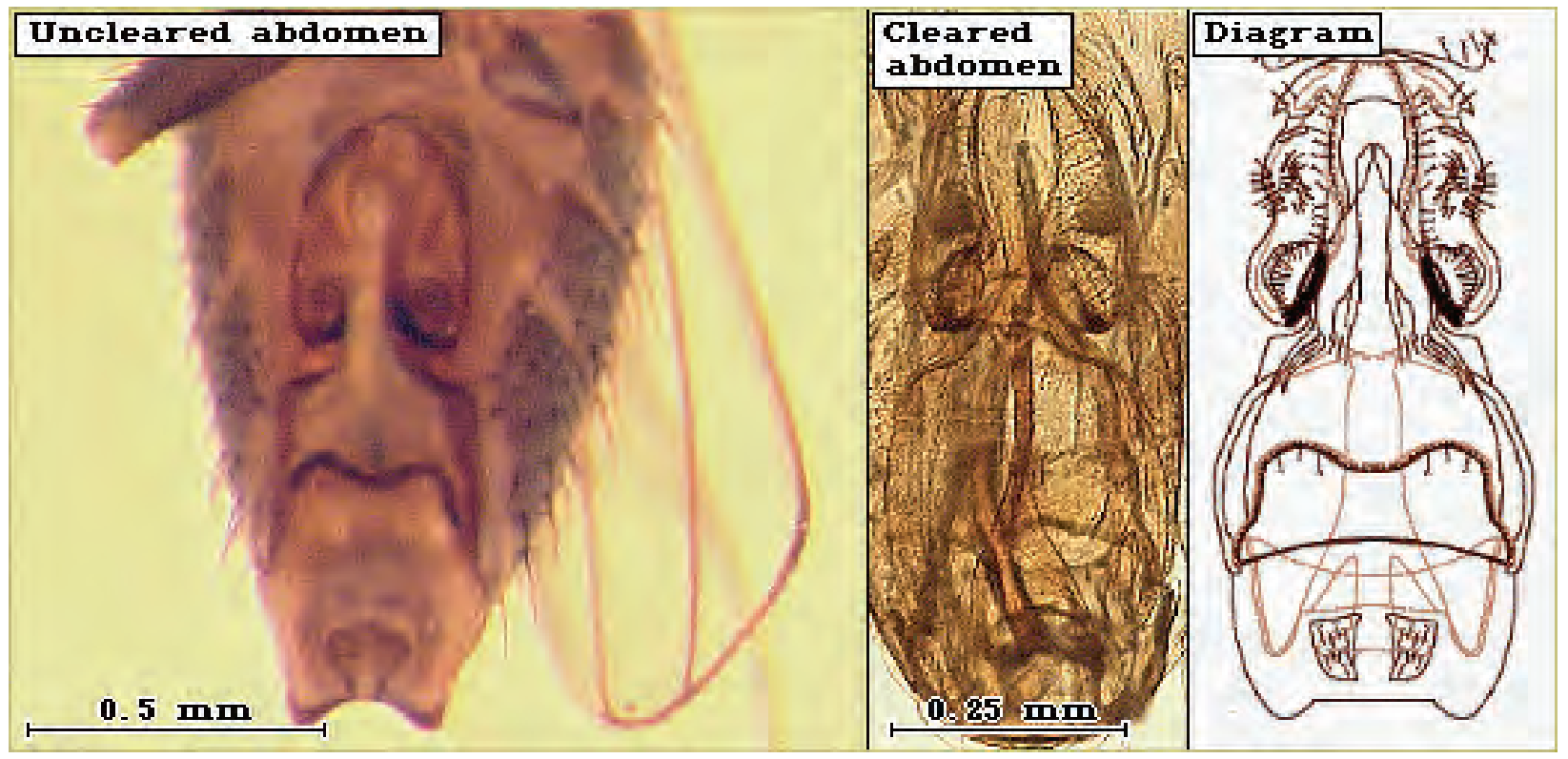

Figure 14. Male - Hydrellia bilobifera - prominent lobes at the base of the abdomen. (Photographs courtesy of the ERDC, 2005, APIS.)

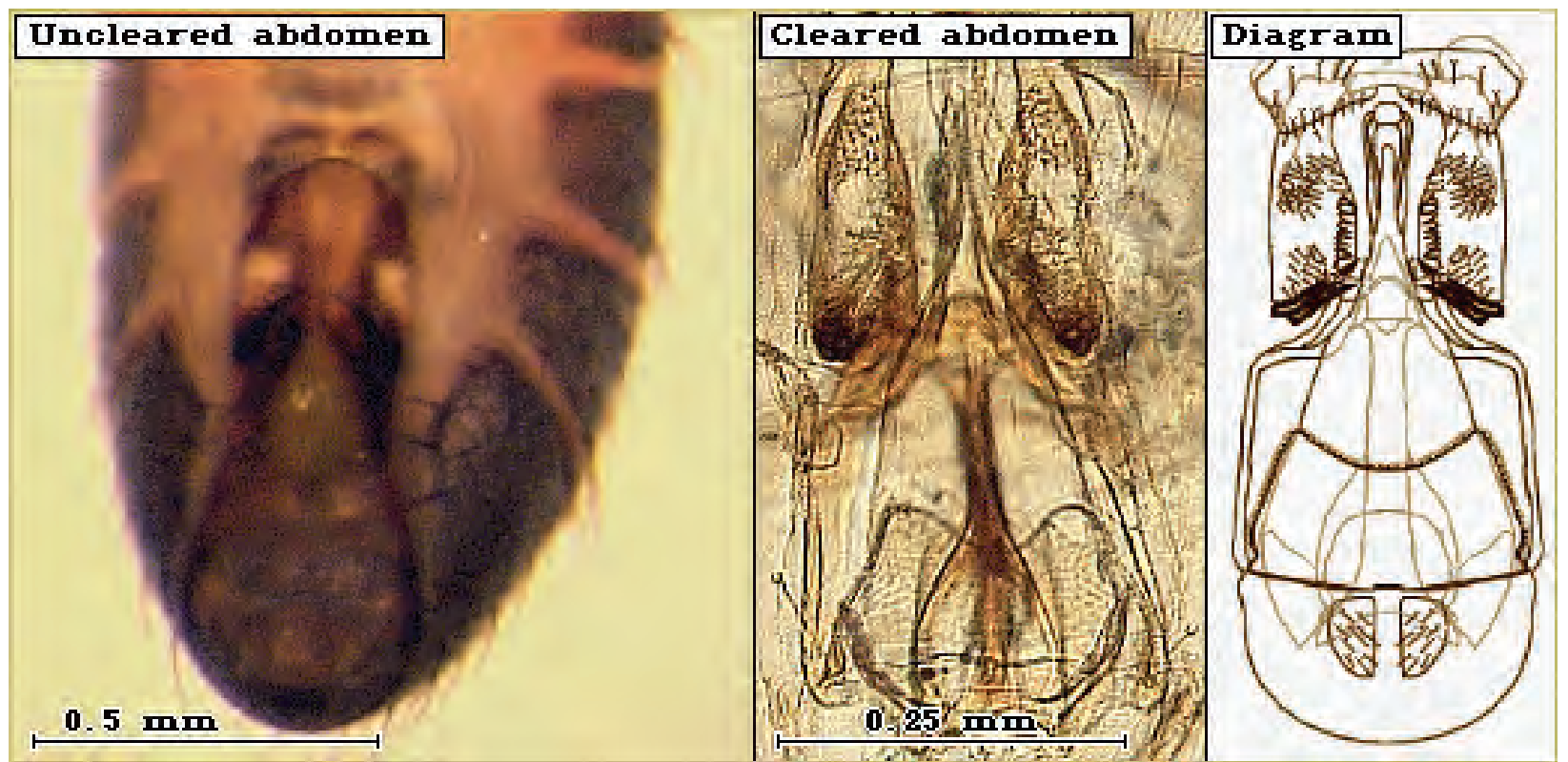

Figure 15. Male - Hydrellia discursa - no lobes at the base of the abdomen.

(Photographs courtesy of the ERDC, 2005, APIS.)

\section{General Information and History}

The family Ephydridae is a large group of insects with ca. 350 North American species including the genus Hydrellia (Borror et al.1976). There are over 50 species of Hydrellia in North America and two of these, $H$. bilobifera and $H$. discursa, have been found in association with the submersed, nuisance aquatic plant, hydrilla (ERDC, 2005, APIS), as well as 
other potentially nuisance native plant species, including several species of pond weeds (Deonier 1971).

\section{Biology}

Hydrellia bilobifera and $H$. discursa look very similar to $H$. pakistanae and $H$. balciunasi, two species of leaf-mining flies that have been introduced as insect biocontrol agents of hydrilla. The primary way to distinguish between the flies is to examine their genitalia (ERDC, 2005, APIS). In female Hydrellia, the cerci are distinctive. In $H$. bilobifera they are long and narrow (Figure 12), and in $H$. discursa, they are short and round (Figure 13). Abdomens are one of the key features to distinguishing between male Hydrellia. The abdomens of the two introduced species are about the same length as their thorax, whereas the native species abdomens' are 1.5 - 2.0 times longer than their thorax (Center et al. 1999, ERDC, 2005, APIS). To distinguish between the two native males, distinctive lobes are found at the base of the abdomen in $H$. bilobifera (Figure 14), but are absent from $H$. discursa (Figure 15) (Center et al. 1999). Another distinguishing characteristic between the native and introduced $\mathrm{Hy}$ drellia is that the adult $H$. bilobifera and $H$. discursa are generally larger (1.6-2.3 mm long) than the introduced flies, H. pakistanae and $H$. balciunasi (which are only 1-2 mm long) (Center et al. 1999).

\section{Host-Specificity}

The host plants of $H$. bilobifera include four species of pondweed (Potamogeton spp.) and horned pondweed (Zannichellia palustris L.), while the primary host plant of $H$. discursa is grass-leaved pondweed ( $P$. gramineus L.) (ERDC, 2005, APIS). Hydrilla is also considered a host plant, and the larvae of both $H$. bilobifera and $H$. discursa feed on the leaves and stems of hydrilla (Center et al. 1999). Several generations of these two insect species can be reared on hydrilla (ERDC, 2005, APIS).

\section{Research/Impact}

The primary research that has been accomplished on these insects is to establish important genitalia characteristics to be able to distinguish them from the two introduced species as well as other native Hydrellia (Deonier 1971, ERDC, 2005, APIS). Also as mentioned earlier, several generations of $H$. bilobifera and $H$. discursa were reared successfully using only hydrilla. 
Both native Hydrellia are often found in association with hydrilla but only $H$. bilobifera is known to feed and develop on hydrilla (ERDC, 2005, APIS). The larval stage of $H$. bilobifera lasts 14 to 31 days in which time it damages ca. twenty hydrilla leaves (Center et al. 1999). Because H. discursa is often found on hydrilla, it is assumed that they feed on hydrilla. It is not certain, however, if $H$. discursa feeds and develops on hydrilla (ERDC, 2005, APIS).

\section{Possible Use in Control Programs}

Since $H$. bilobifera (and assuming $H$. discursa) feed on hydrilla causing damage to the leaves and stems, they should be considered for use in hydrilla biocontrol programs, possibly to supplement populations of the two introduced species. As they are native and have been found in association with hydrilla infestations and have been reared successfully on hydrilla (ERDC, 2005, APIS), mass-rearing these insects might be beneficial to aid biocontrol programs in the management of hydrilla. In addition, more information is needed to determine if these species could be used to manage nuisance populations of several species of native aquatic plants.

\section{Mycoleptodiscus terrestris (Gerd.) Ostazeski Fungi, Ascomycota, Ascomycetes, Sordariomycetidae, Incertae sedis, Magnaporthaceae (Figures 16-18)}

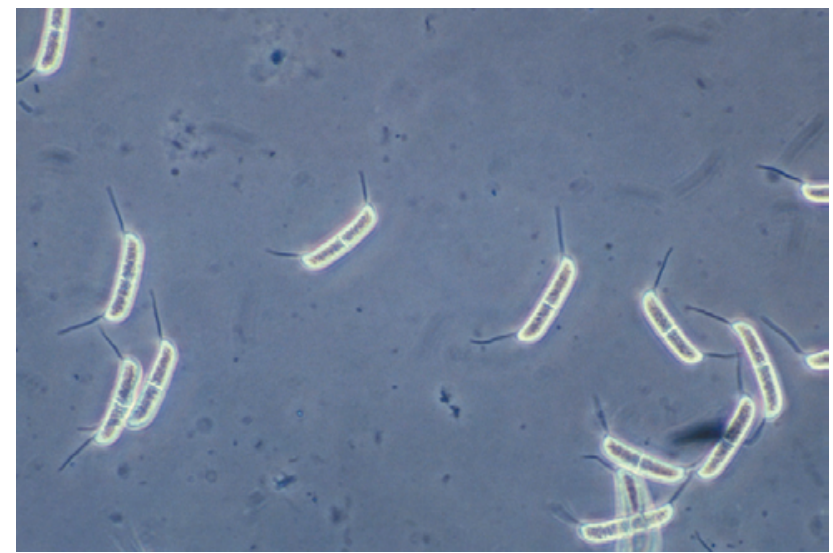

Figure 16. MT spores. (Photograph courtesy of Dr. Judy Shearer.)

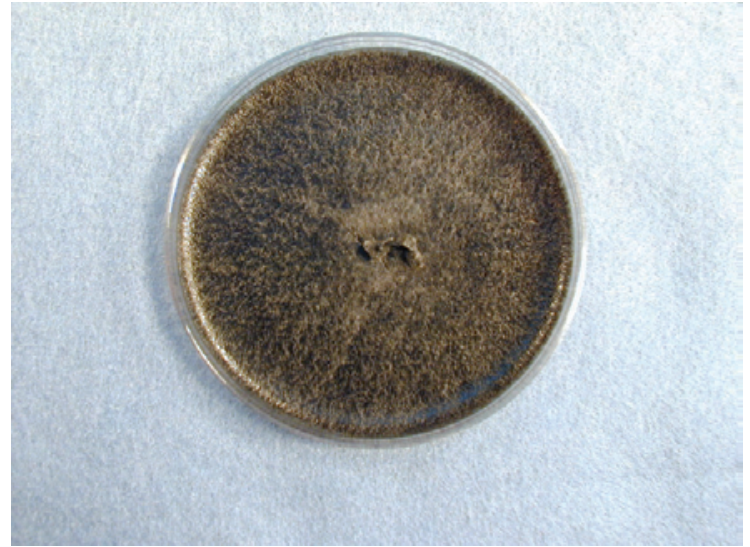

Figure 17. MT on plate. (Photograph courtesy of Dr. Judy Shearer.) 


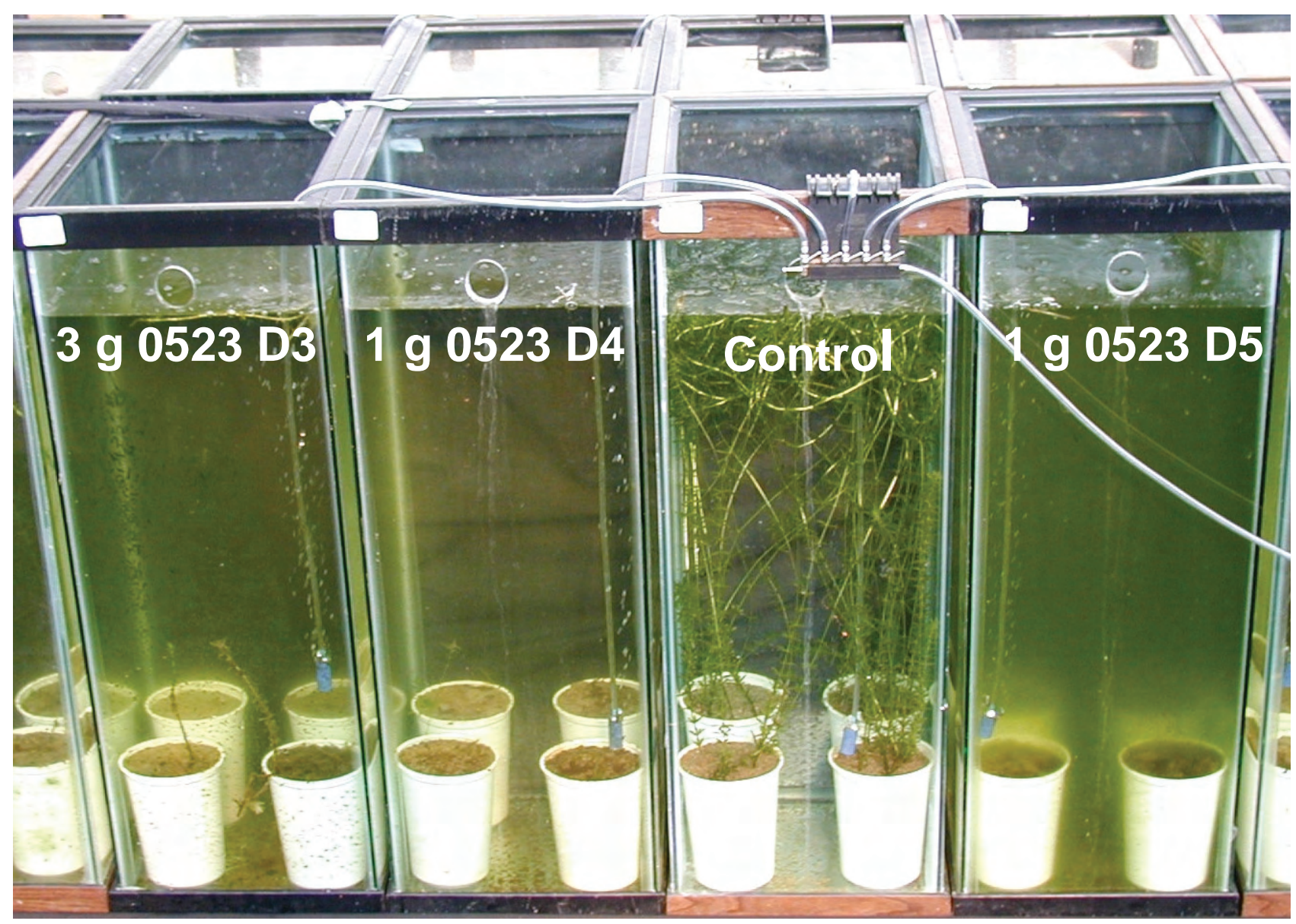

Figure 18. Mt aquaria study on hydrilla - the legend tells the amount of dry pathogen used (g), the experiment it came from (523), and the number of days the fermentation ran before harvesting (D). (Photograph courtesy of Dr. Judy Shearer.)

\section{General Information and History}

In the fall of 1987 and 1988, surveys were conducted in 15 lakes and 3 rivers in the southeastern U.S. to test for the presence of pathogens of hydrilla (J oye and Cofrancesco 1991). About 200 fungal and 27 bacterial isolates were collected, and a promising candidate was isolated from hydrilla foliage growing in Lake Houston, Texas (J oye 1988, 1989, 1990). Originally identified to be the indigenous fungal pathogen Macrophomina phaseolina (Tassi) Goid. (J oye 1990), it was later discovered to be Mycoleptodiscus terrestris (Gerd.) Ostazeski, Mt (Shearer 1996a). Dr. Bruce Sutton, a world authority on Coelomycetes, at the International Commonwealth Institute, England, verified the identification of Mt (Shearer 1996a).

Isolations of Mt were also made from EWM collections from Massachusetts and Alabama in the late 1970s (Gunner 1983, personal communica- 
tion Dr. J udy Shearer, 2005). It was considered to be a promising biocontrol candidate for EWM and early greenhouse and laboratory studies showed that Mt reduced milfoil biomass (Gunter et al. 1990, Stack 1990, Smith and Winfield 1991). Mt was developed into a mycoherbicide, AquaFyte ${ }^{\circledR}$, by EcoScience Corporation, Worcester, MA. Work conducted by Shearer (1994), showed that Aqua-Fyte ${ }^{\circledR}$ was ineffective in reducing the biomass of EWM under natural field conditions. Shearer (1996b) also demonstrated that while the pathogen Mt was very effective in greenhouse tests on EWM, field trials exhibited inconsistent results.

\section{Biology}

Mt is a dematiaceous fungus that reproduces asexually by hyaline twocelled spores (Figure 16) or by melanized survival structures called microsclerotia. No sexual stage is known. The spores arise from phialides that aggregate to form a one cell thick structure called a sporodochium. On standard laboratory media (Figure 17), the fungus does not produce spores but readily produces microsclerotia. Applied as a fungal suspension of hyphae and microsclerotia, J oye and Paul (1992) observed that the fungus is capable of attaching to hydrilla tissues in less than 24 hours and within 40 hours penetration through the cell wall is complete. Within 196 hours, complete colonization of hydrilla tissue was observed. Associated with fungal colonization was loss of cellular integrity followed by total plant collapse (Figure 18).

\section{Host-Specificity}

Host-specificity tests conducted by J oye and Cofrancesco (1991) showed that the fungal plant pathogen was nonpathogenic to 44 of 46 species and subspecific taxa within 22 families. They found that only hydrilla and duck lettuce (Otellia alismoides (L.) Pers.) were susceptible.

\section{Research/Impact}

Applied as a fungal suspension at rates of $0.2 \mathrm{ml} \mathrm{L}^{-1}$, hydrilla shoot biomass reductions of 99-100 percent have been achieved in greenhouse trials. In more recent studies using $0.04 \mathrm{~g} \mathrm{~L}^{-1}$ of dried Mt, similar reductions have been recorded.

Mt was proven by both J oye (1990) and Shearer (1996a) to be a potential biocontrol agent of hydrilla. Field and greenhouse studies conducted by 
both scientists showed that Mt significantly reduced hydrilla biomass after inoculation compared with untreated plants. Disease symptoms appeared in 5 to 7 days, and within 10 to 14 days, plants started to disintegrate. Other research being conducted by Drs. J udy Shearer and Linda Nelson (ERDC, Vicksburg, MS) integrates Mt with the herbicides fluoridone, endothall, and 2,4-D (Nelson et al. 1998, Nelson and Shearer 2002, Shearer and Nelson 2002, Nelson and Shearer 2005) to observe whether there is improved activity with the combination of pathogen and herbicide for aquatic plant management as opposed to using either method independently. Earlier work done by Netherland and Shearer (1996), demonstrated a potential for combining the two technologies, chemical and biological control, for the management of hydrilla.

\section{Possible Use in Control Programs}

Currently, Mt is being evaluated as a potential bioherbicide for hydrilla management (Balciunas et al. 2002). An Mt isolate collected on hydrilla in Texas (at a site different than Lake Houston) has proven to be the most successful of all isolates collected both in the U.S. and overseas (August 2004, personal communication, Dr. J udy Shearer). This isolate is deposited in the culture collection at the United States Department of Agriculture, Agriculture Research Service, National Center for Agricultural Utilization Research (USDA, ARS, NCAUR) in Peoria, IL. The accession number for this isolate is NRRL Number 30559. Dr. Judy Shearer and Dr. Mark J ackson, USDA, ARS, NCAUR, Peoria, IL, are studying fermentation methods that will yield high concentrations of effective Mt propagules at a low cost. They have received a U.S. patent for the procedures. It is hoped that a bioherbicide can be produced that will be as effective and can be used alone or in an integrated approach with chemical herbicides. 
Ostrinia penitalis (Grote), American Lotus Borer (Lepidoptera: Pyralidae: Pyraustinae) (Figure 19)


Figure 19. American lotus borer, adult, larvae, and larval damage.

(Photographs courtesy of the ERDC, 2005, APIS.)

\section{General Information and History}

The subfamily Pyraustinae is a large group of insects comprising over 300

North American species. Many of its members are relatively large and conspicuously marked (Borror et al. 1976). The most important species in this subfamily is the European corn borer (Ostrinia nubilalis (Hubner)). Closely related to the European corn borer is the American lotus borer (O. penitalis (Grote)). The American lotus borer is generally found in association with its preferred host plant, American lotus, but it also feeds on various species of smartweeds (Polygonum spp.) (Center et al. 1999). 


\section{Biology}

Adult American lotus borers are medium-sized moths that are yellowish to orange in color (Figure 19 - Adult) (ERDC, 2005, APIS). Females lay their eggs in groups of about 60 on the upper surface of lotus leaves (Center et al. 1999). The larvae feed on the outer edges of leaves staying attached by a series of fine silken strands that keep them from being swept away by wind or wave action (Figure 19 - Larva and damage) (ERDC, 2005, APIS).

When the larvae feed near the leaf edges, they frequently roll an entire portion of the leaf around themselves (ERDC, 2005, APIS). Once the larvae mature, they stop feeding and burrow into the leaf petiole to pupate. Once pupation is completed, the adults emerge from previously formed exit holes (ERDC, 2005, APIS).

\section{Host-Specificity}

The primary host of the American lotus borer is American lotus, but they also feed on many species of smartweeds and knotweeds (Polygonum spp.) including denseflower knotweed (P. densiflorum Meisn.), marshpepper knotweed ( $P$. hydropiper L.), and dotted smartweed ( $P$. punctatum Ell.) (ERDC, 2005, APIS).

\section{Research/Impact}

Ostrinia penitalis can cause devastating damage to lotus beds where the extensive feeding can reduce the leaves to mere skeletons (ERDC, 2005, APIS). Emergent seed heads are often attacked by larvae, which consume the immature seeds (Center et al. 1999).

\section{Possible Use in Control Programs}

Ostrinia penitalis is a serious herbivore of American lotus since a single larva can cause leaf deterioration as well as attack the buds and seedcapsules (Welch 1919). Depending on the number of larvae present on a plant, the leaves will show signs of deterioration and loss of chlorophyll tissue will ensue (Welch 1919). When the larvae reach a certain size (ca. $14 \mathrm{~mm}$ ), they begin to burrow into the plant. The burrow construction eventually severs the leaf connection from the rootstock and results in the ultimate destruction of the floating part of the American lotus (Welch 1919). More information is needed on life history, host-specificity, seasonal dynamics, and mass-rearing procedures before their use can be ascertained. 


\section{Parapoynx diminutalis Snellen, Asian Hydrilla Moth, (Lepidoptera: Pyralidae: Nymphulinae: Nymphulini) (Figure 20)}
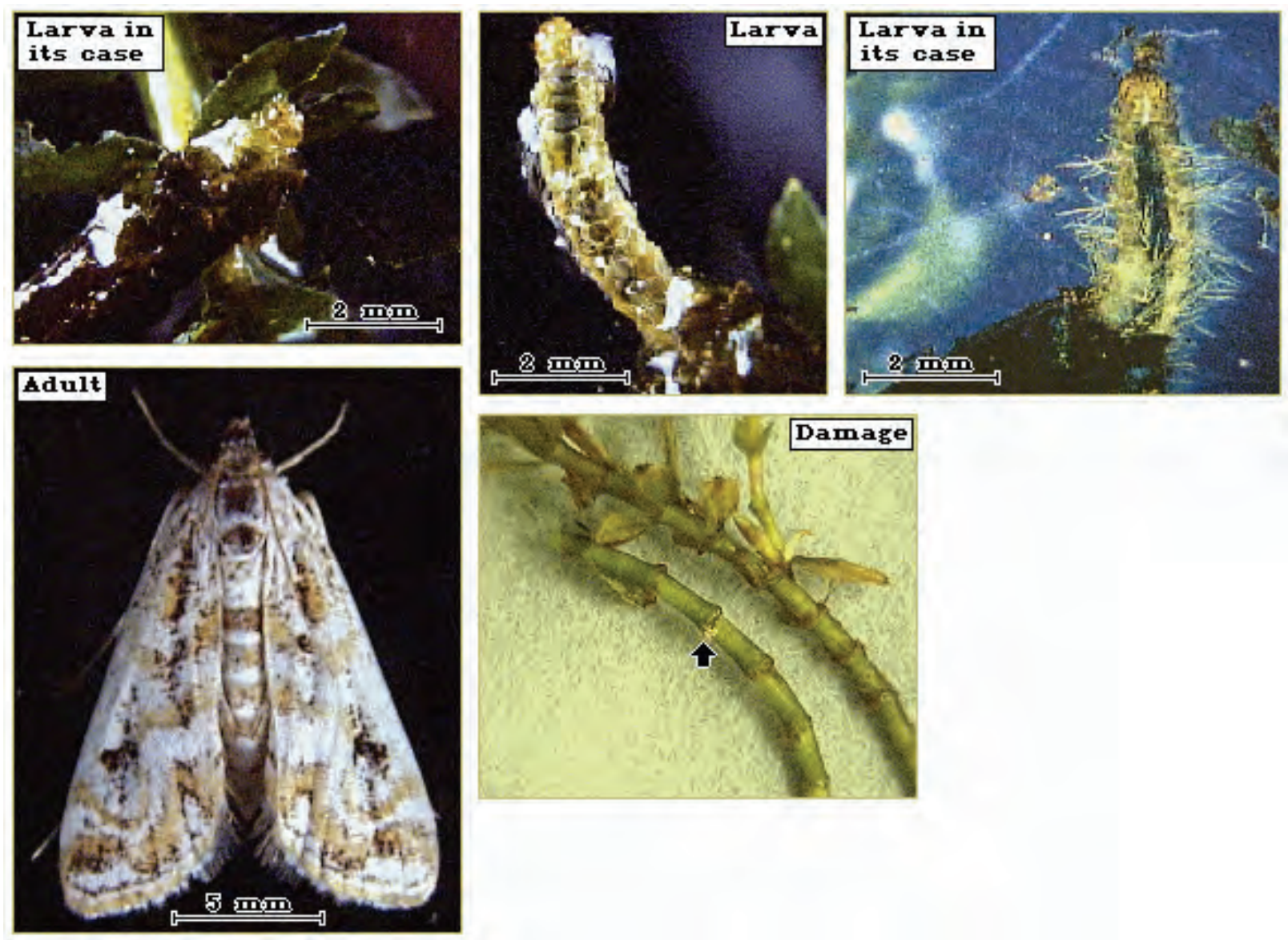

Figure 20. The Asian hydrilla moth larvae, adult, and damage to hydrilla. (Photographs courtesy of the ERDC, 2005, APIS.)

\section{General Information and History}

Center et al. (2002) describe the subfamily Nymphulinae as a group of moths that are almost all aquatic, with 18 species occurring in Florida. The Asian hydrilla moth (Parapoynx diminutalis Snellen), known from Pakistan to Southeast Asia (Delfosse et al. 1976), was first reported in Florida in 1976 feeding on hydrilla (Balciunas and Habeck 1981, Balciunas et al. 2002). It was probably brought into the state through the aquarium industry (Balciunas et al. 2002).

\section{Biology}

The female Asian hydrilla moth (Figure 20 - Adult) lays eggs in masses of about 30, placed on hydrilla leaves and stems that are exposed at the surface of the water (Center et al. 2002). Eggs hatch in about 4 to 6 days and 
larval development takes 21 to 35 days, depending on the temperature. Young larvae feed by scraping the leaf surface or by notching the leaf margin (Figure 20 - Larva and damage). First and second instars sometimes feed within a simple case made by attaching a small piece of leaf wrapped over them. Later instars make tubular cases from stems or leaves that attach to one another with silk (Figure 20 - Larva in its case). Pupae are enclosed in an air-filled white silken cocoon attached to one side of the submersed hydrilla stem (Buckingham and Bennett 1996).

\section{Host-Specificity}

Laboratory tests conducted by Buckingham and Bennett (1989) found that the larvae of the Asian hydrilla moth developed on 14 plant species in13 genera. Larvae also developed on three combinations of species: (1) waterlily (Nymphaea spp.) and fragrant waterlily (N. odorata Ait.); (2) naid (Najas minor All) and southern naid (N. guadalupensis (Spreng.) Magnus); and (3) horned pondweed (Zannichellia pulstris L.) and needle spikerush (Eleocharis acicularis (L.) Roemer and Schultes). Hydrilla was usually the preferred host by larvae when paired with a test plant, but it was not the preferred host by ovipositing females in small-cage tests. These tests indicated that the following plants might be at risk for larval attack in the field: fanwort (Cabomba caroliniana A. Gray), coontail (Ceratophyllum demersum L.), egeria (Egeria densa Planch.), southern naiad, and EWM.

\section{Research/Impact}

Further testing by Buckingham and Bennett (1996) found that P. diminutalis larvae could be very damaging to hydrilla planted in pools or other protected containers in Florida. Larvae were also found frequently on other plant species associated with hydrilla in their research plantings. In addition to hydrilla, they found immatures in the field on coontail (1 larva, 1 pupa), southern naiad (2 larvae), and Illionois pondweed (Potamogeton illinoensis Morong) (5 larvae, 3 pupae). This contrasted sharply with the 14 plant species in 13 genera that produced adults in their initial host range tests (Buckingham and Bennett 1989). The highest percentage of adults (90 percent) was produced on one replicate of fanwort, but the highest average percentage (48\%) was on hydrilla (Buckingham and Bennett 1989). 
Parapoynx diminutalis is well established in both Panama and Florida, but Buckingham and Bennett (1996) feel it would have a greater impact on hydrilla in Panama due to the milder climate. They found that in northcentral Florida near Gainesville, larval populations were reduced to very low levels in the late winter and early spring. These populations rebounded quickly during some years, however, so that by late summer hydrilla stems near the surface had been extensively defoliated.

\section{Possible Use in Control Programs}

Parapoynx diminutalis was once considered as a potential biological control because it severely damages hydrilla growing in culture (Center et al. 1999). The moths only occur sporadically, however, and produce only minimal damage to hydrilla in the field (Center et al. 1999). From the research conducted by Buckingham and Bennett (1996), P. diminutalis would be useful in an integrated hydrilla control program. If augumentation of the moth populations were made in early summer, this might allow the populations to build up fast enough to slow the growth of hydrilla. This coupled with the use of herbicides or pathogens would cause the plants to decline more readily. However, the wide host range may preclude their use. 
Perigaster cretura (Herbst), Primrose Leaf Weevil (Coleoptera: Curculionidae: Curculioninae: Ceutohynchini) (Figure 21)
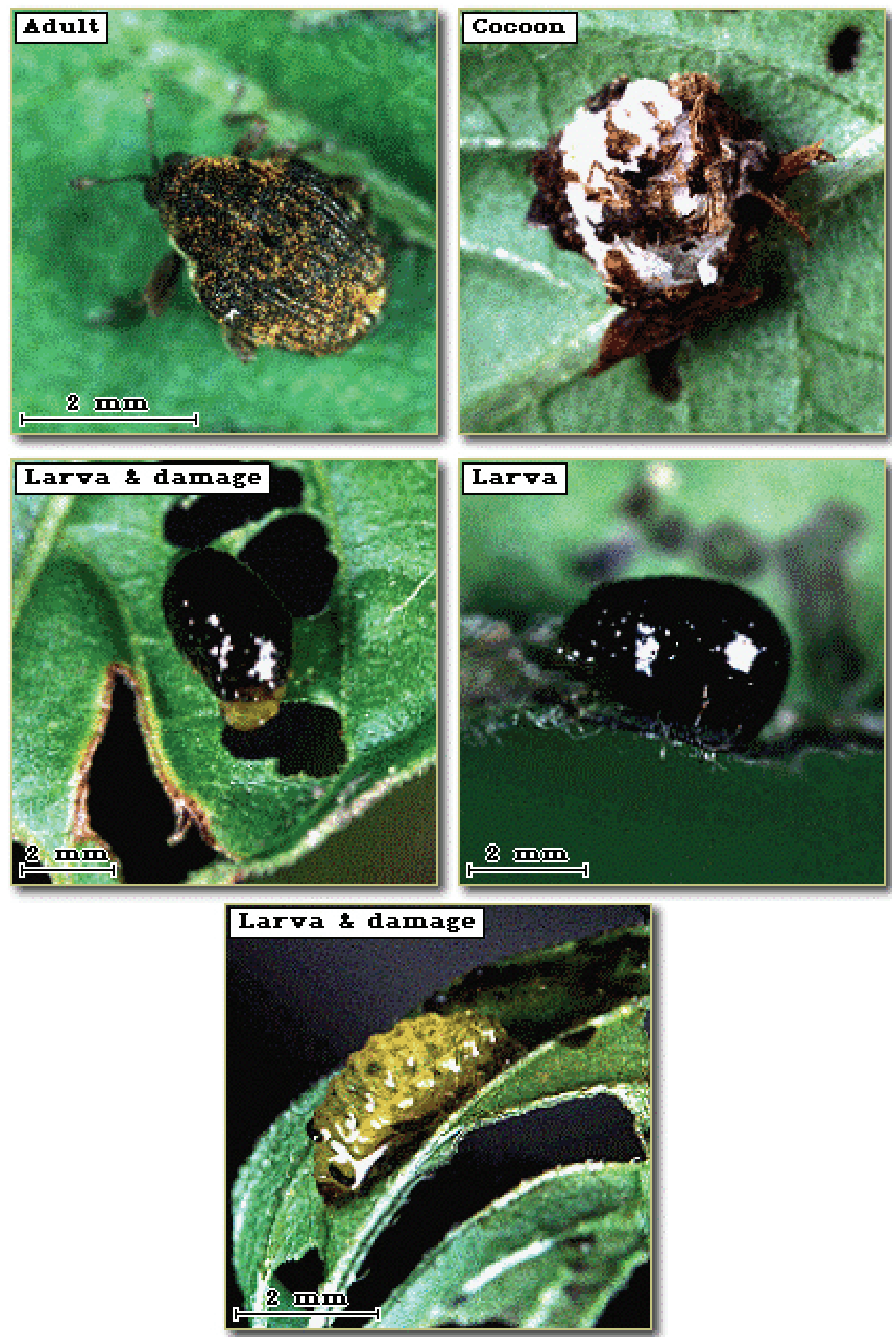

Figure 21. Primrose leaf weevil adult, cocoon, larva, and larval damage. (Photographs courtesy of the ERDC, 2005, APIS.) 


\section{General Information and History}

The genus Perigaster consists of five species. Four species, including $P$. cretura (Herbst), occur in the eastern U.S.; the fifth species is found only in Panama (Clark 1976). Perigaster cretura feeds on species of water-primrose (Ludwigia spp.) (Clark 1976). The weevils are small $(<3 \mathrm{~mm}$ ) and feed during the day generally on the upper leaf surfaces of their host plants (Center et al. 1999, ERDC, 2005, APIS). When disturbed, the adults can jump, readily taking flight (Center et al. 1999). They are also able to create a creaking sound by rubbing ridged surfaces of their body together (Center et al. 1999).

\section{Biology}

Primrose leaf weevils are roundish in outline, brown to reddish brown in color with mottling of black and white (Figure 21 - Adult) (Center et al. 1999, ERDC, 2005, APIS). When handled, they tuck their snout and legs against their body "playing dead" (ERDC, 2005, APIS). The larvae develop through three instar phases, covering themselves with a protective layer of their own excrement (Clark 1976). Pupation occurs in a cell formed from a secreted material, excrement, and bits of debris (Figure 21 - Cocoon) (Clark 1976). When the adult emerges, it chews a hole through the upper portion of the pupal cell (Center et al. 1999, ERDC, 2005, APIS).

\section{Host-Specificity}

Plant hosts of the primrose leaf weevil include Mexican primrose-willow (Ludwigia octovalvis), floating primrose-willow (L. peploides), creeping primrose-willow (L. repens), and seedbox (L. alternifolia) (Center et al. 1999, ERDC, 2005, APIS).

\section{Research/Impact}

Both the larvae and adult feed on the leaves of water-primrose, creating numerous small holes throughout the leaves (ERDC, 2005, APIS). Larval feeding activity is especially extensive as they develop through their three instar phases (Figure 21 - Larva and damage) (Center et al. 1999).

\section{Possible Use in Control Programs}

Ludwigia spp., although native to North and South America, is considered to be a nuisance plant in most of its range (Balsbaugh and Hays 1972; 
Aurand 1982, Chester and Hold 1990, McGregor et al. 1996). Since the plant hosts of $P$. cretura include four species of Ludwigia, this insect should be considered and studied as a potential candidate for waterprimrose management.

Simyra henrici (Grote), Cattail Caterpillar (Lepidoptera: Noctuidae: Acronictinae) (Figure 22)
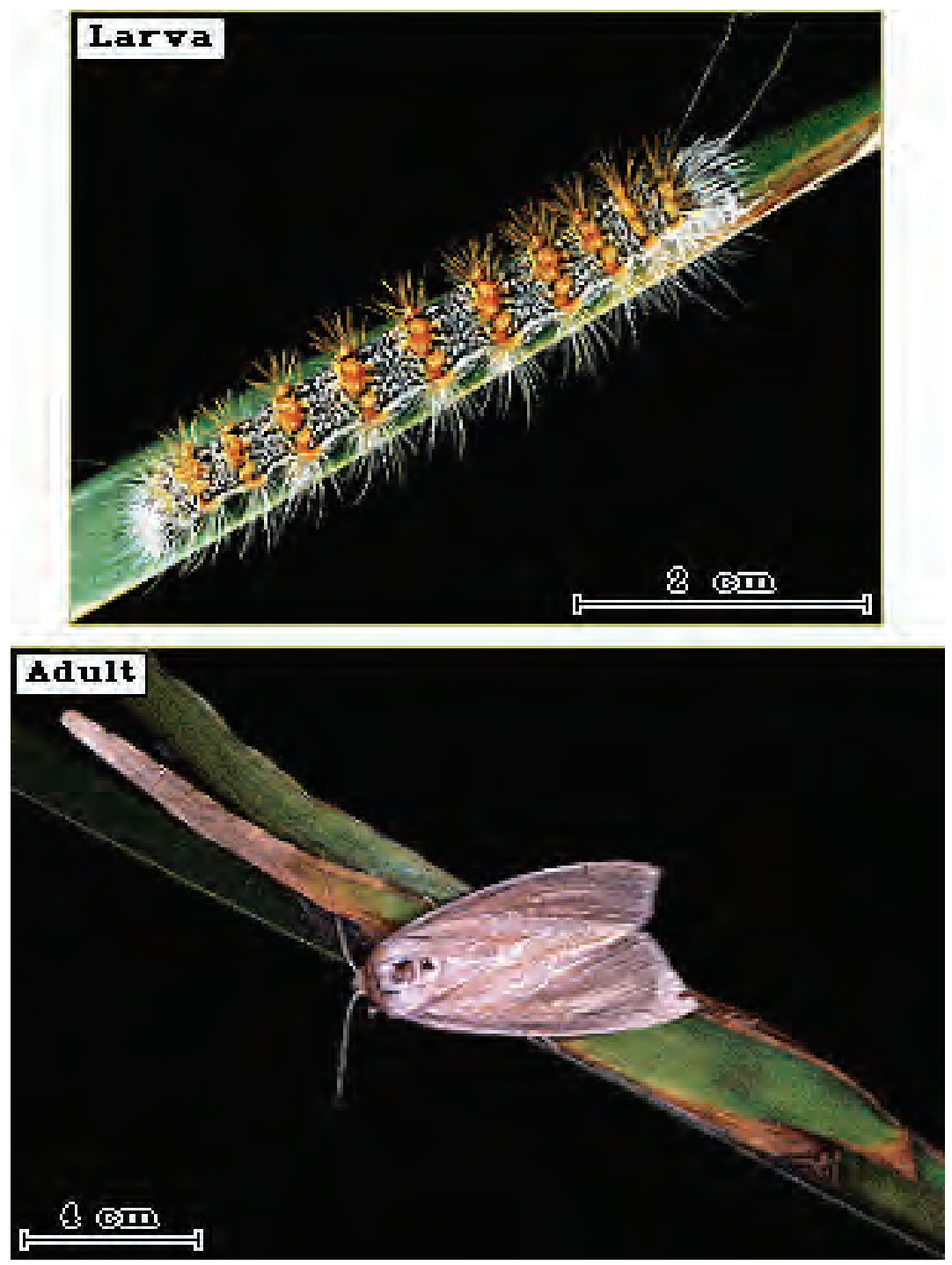

Figure 22. Cattail caterpillar larva and adult. (Photographs courtesy of the ERDC, 2005, APIS.)

\section{General Information and History}

The cattail caterpillar (Simyra henrici) is widespread and commonly found feeding on cattails (Typha spp.) (ERDC, 2005, APIS). It has also been recorded feeding on many other plant species including buttonbush 
(Cephalanthus occidentalis L.), poplars (Populus spp.), smartweeds (Polygonum spp.), willows (Salix spp.), sedges (Carex spp.), and grasses (Family - Poaceae) (Center et al. 1999).

\section{Biology}

Information from the ERDC, 2005, APIS, and Center et al. (1999), describes adult $S$. henrici as large moths having a wingspan of 34 to $45 \mathrm{~mm}$ (Figure 22 - Adult). Females lay flattened, grayish-white eggs in batches of from 60 to more than 150 eggs per batch. Batches can be composed of up to seven overlapping rows of eggs, with individual females having the capability of laying over 1,700 eggs.

Larvae develop through seven instar stages during an approximate 30-day period. Mature larvae are orange and brown on top, light brown underneath, and covered with hairs (Figure 22 - Larva). Larvae use silk to tie two adjacent cattail leaves together to form a pupation area. Within the pupation area, a silken cocoon is created in which the insect pupates. Total development time from egg to adult is ca. 6 to 7 weeks (Center et al. 1999).

\section{Host-Specificity}

In host-specificity studies conducted by Cassani (1985), field-collected second and fifth instar $S$. henrici larvae were placed on one of five different plant species: cattail, swamp smartweed (Polygonum hydropiperoides Michx.), common buttonbush (Cephalanthus occidentalis), torpedo grass (Panicum repens L.), and swamp willow (Salix caroliniana Michx). On swamp smartweed and swamp willow, at least 20 percent of the second and fifth instar larvae completed development through pupation. Larval mortality was 100 percent on both common buttonbush and torpedo grass, contradicting earlier literature that common buttonbush and grasses are host plants of $S$. henrici. Cattail seemed to be the preferred host plant, but Cassani (1985) did not feel that the host range of $S$. henrici was narrow enough to be considered as a biocontrol agent of cattail, at least not in south Florida. 


\section{Research/Impact}

Cattail seems to be the preferred host plant of $S$. henrici (Cassani 1985). In Florida, feeding by this insect has dramatically impacted large areas of cattail stands (Center et al. 1999, ERDC, 2005, APIS).

\section{Possible Use in Control Programs}

Cassani (1985) does not feel that the host range of $S$. henrici is narrow enough to warrant its manipulation for control of cattail, at least not in south Florida. Further host range research should be conducted from other geographic locations before any attempt is made to manipulate $S$. henrici as a biological control agent. 
Synclita obliteralis (Walker), Waterlily Leafcutter, (Lepidoptera: Pyralidae: Nymphulinae: Nymphulini) (Figures 23 and 24)
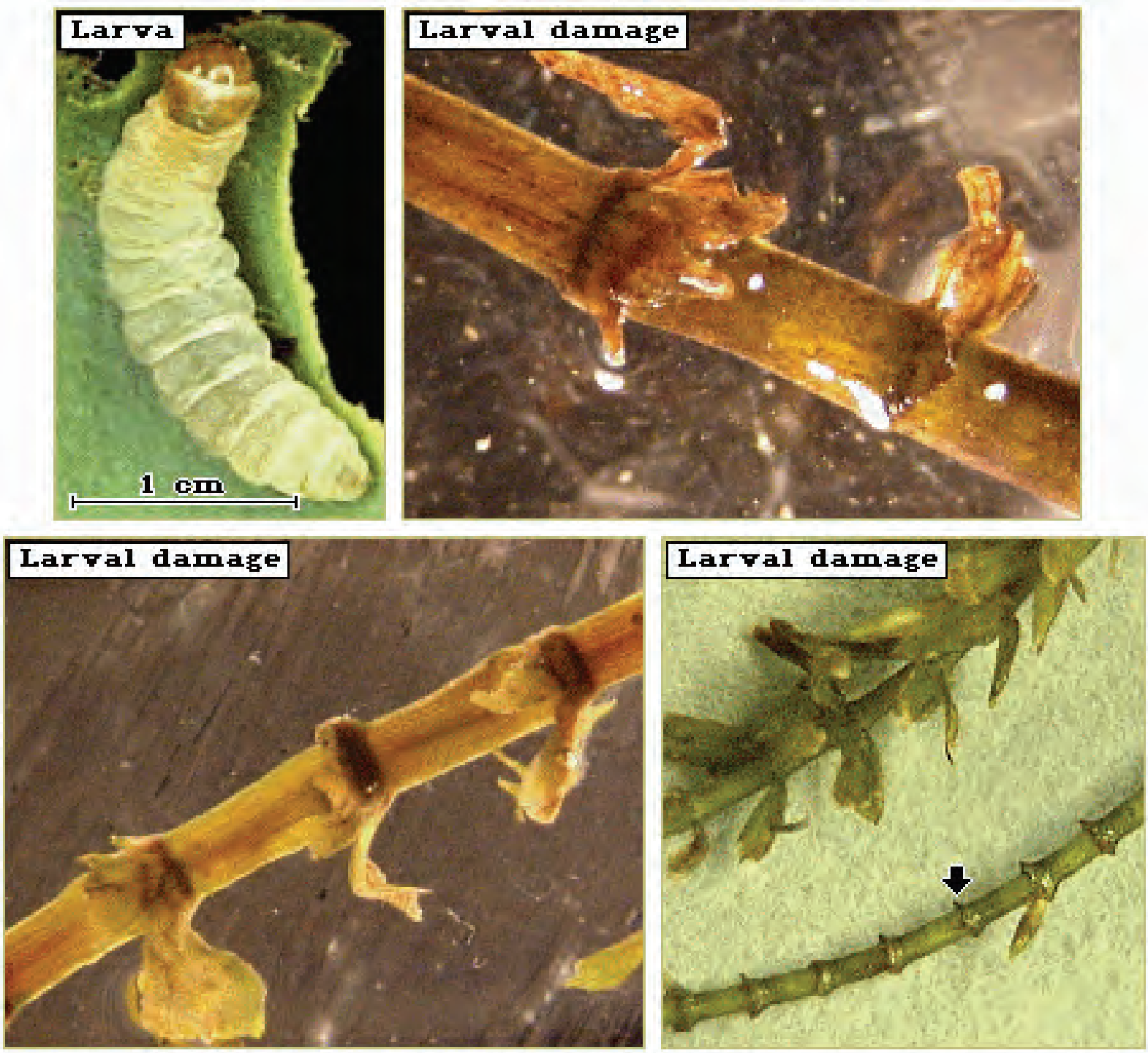

Figure 23. Waterlily leafcutter larva and larval damage.

(Photographs courtesy of the ERDC, 2005, APIS.) 


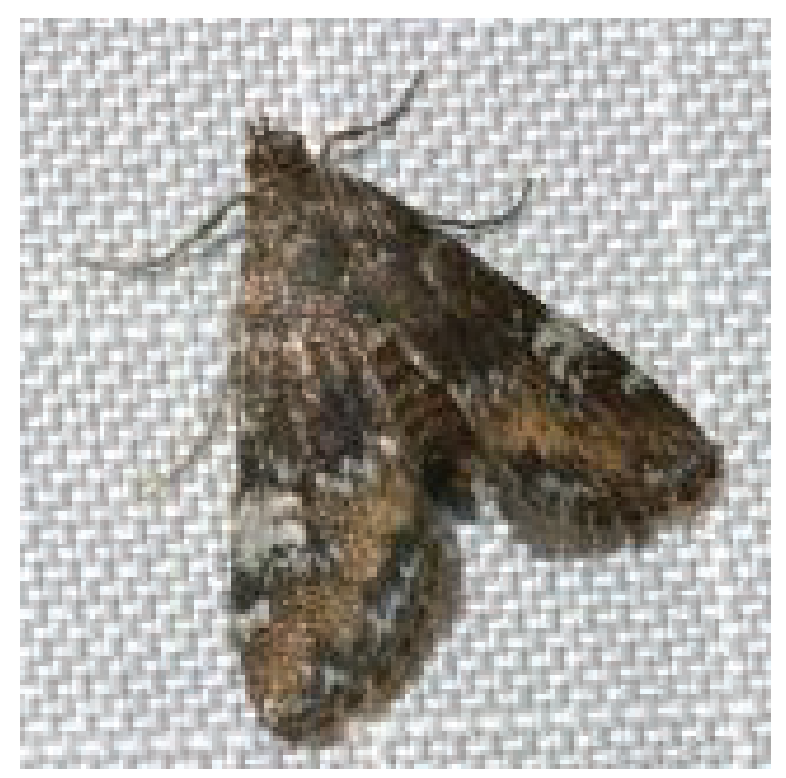

Figure 24. Waterlily leafcutter adult. (Photograph courtesy of http://www.pbase.com/tmurray74/pyraloidea through pyralinae moths, No. 4755 - Waterlily Leafcutter Moth - Synclita obliteralis [Murray 2005].)

\section{General Information and History}

Although adult waterlily leafcutters are moths, the larvae of most Nymphulinae are aquatic, breathing by means of gills, and feeding on aquatic plants (Figure 23 - Larva and larval damage) (Borror et al. 1976). Although the name, waterlily leafcutter, suggests that this insect feeds only on waterlilies, in actuality it feeds on more than 60 species of aquatic plants including hydrilla, waterhyacinth, waterlettuce, Salvinia spp. and Myriophyllum spp. (Center et al. 1999). In all, the total food plant list includes 23 plant families (Center et al. 1999).

\section{Biology}

Adult waterlily leafcutters are small, dark-colored moths with brown and white markings (Figure 24 - Waterlily leafcutter adult) (Lange 1956; Kinser and Neunzig 1981; Habeck 1991; ERDC, 2005, APIS). The females are the larger of the two with a wingspan of 15 to $19 \mathrm{~mm}$ compared to 11 to $13 \mathrm{~mm}$ for males (Habeck 1991). The female moths lay eggs near the edges of submersed aquatic plant leaf surfaces (Center et al. 1999). Once the eggs hatch, larvae live within a round case formed by two pieces of leaves that create an air-filled case (younger larvae may have cases filled with water) (Habeck 1991). When the larvae are ready to pupate, they spin a cocoon within their leaf case (Center et al. 1999). 


\section{Research/Impact}

Information obtained from the ERDC, 2005, APIS, describes waterlily leafcutter caterpillar damage as distinct cuts on the leaves of waterhyacinth and similar damage to the floating leaves of waterlettuce. Larvae will also form small cases made from hydrilla leaf pieces where they will exist while feeding on the exposed and submersed areas of the plant (Figure 23 - Larva and Larval damage).

\section{Possible Use in Control Programs}

Synclita obliteralis is an extremely polyphagous insect, feeding on and utilizing many kinds of aquatic plants for food (Center et al. 1999). In aquatic plant nurseries, it can become a serious problem, especially on waterlilies, but aside from this, studies have not been conducted on its possible use in control programs. Because it does attack a wide variety of nuisance aquatic plants including waterlettuce, waterhyacinth, hydrilla, and salvinia, further work should be conducted to review the usefulness of the waterlily leafcutter as a potential biocontrol agent. More information is also needed on its impact to native plants, especially those used in revegetation efforts as a way to reduce hydrilla invasiveness. 


\section{Future Direction}

To date there have not been many successful biocontrol programs using native/naturalized herbivores/ pathogens to control exotic plants, however, there are several promising candidates on the horizon. Dr. Judy Shearer, ERDC, Vicksburg, MS, and Dr. MarkJ ackson, USDA, ARS, NCAUR, Peoria, IL, are making great strides with the on-going research of using Mycoleptodiscus terrestris as a potential bioherbicide for hydrilla management. A company in Stowe, Ohio, EnviroScience, Inc., has available for sale a MiddFoil ${ }^{\circledR}$ process which includes purchasing milfoil weevils (Euhrychiopsis lecontei) for the management of EWM. The salvinia weevil (Cyrtobagous salvinia), has also been used successfully as a biocontrol agent of Salvinia spp. Water-primrose (Ludwigia spp.), although native to North and South America, is considered to be a nuisance plant in some cases, and the water-primrose flea beetle (Altica ludoviciana) has shown promise as a potential biocontrol agent. Altica litigata, another water-primrose flea beetle, has shown success by feeding on other species of Ludwigia - L. octovalvis and L. palustris with the added bonus of feeding on purple loosestrife (Lythrum salicaria).

According to Smart and Doyle (1995), to successfully restore a waterway infested with aggressive, nuisance aquatic plants, an integration of management tools is required including chemical control, biological control, mechanical control, and drawdowns. These methods must be used altogether along with an ecologically based plant competition strategy. The use of biocontrol agents would make it possible for reservoir managers to keep aquatic, nuisance plant growth in check (Smart and Doyle 1995). This would in turn allow for the introduction of native species or, if they are already present, allow them to grow without being overpowered by the exotics. 


\section{Summary}

Future and continued research using native/ naturalized herbivores/ organisms for controlling and managing nuisance aquatic plants is needed. Funding for biological control research is becoming increasingly scarce. It is becoming difficult and costly to fund scientists to explore countries where introduced, nuisance plants originate in hopes of collecting and identifying potential biocontrol agents. Studying naturalized and native herbivores and pathogens that impact nuisance aquatic and wetland plants would increase the number of potential biocontrol agents that could be incorporated into invasive plant management programs. The groundwork has been laid for conducting future biocontrol research and experimentation. Although not all of the native and naturalized organisms discussed can be successful, the information and expertise is now available for potential insects and pathogens to be collected, analyzed, and studied. A continuation of the work that has been started is needed to make available for the future more successful native biocontrol agents.

Research is being conducted by ERDC scientists to identify naturalized and / or native herbivores of aquatic plants in an effort to develop alternative management strategies through an understanding of the agents' biology and ecology. Some of the native species that are showing promise as biocontrol agents include Altica spp. for water primrose, Donacia spp. for American lotus, and Euhrychiopsis lecontei for Eurasian watermilfoil control. Naturalized species with possibility include Cyrtobagus salviniae for common and giant salvinia, and Parapoynx diminutalis for hydrilla. 


\section{References}

Aurand, D. 1982. Nuisance aquatic plants and aquatic plant management programs in the United States, Vol. 2. Southeast Region. McLean, VA: The Mitre Corporation, 117-119.

Balciunas, J. K., and D. H. Habeck. 1981. Recent range extension of hydrilla-damaging moth, Parapoynx diminutalis (Lepidoptera: Pyralidae). Florida Entomologist 64: 195-196.

Balciunas, J . K., M. J . Grodowitz, A. F. Cofrancesco, and J . F. Shearer. 2002. Hydrilla. In Biological control of invasive plants in the Eastern United States. R. V. Driesche, S. Lyon, B. Blossey, M. Hoddle, and R. Reardon, ed. FHTET - 2002- 04. 91-109. USDA Forest Service Publication.

Balsbaugh, E.U., J r., and K. L. Hays. 1972.The leaf beetles of Alabama (Coleoptera: Chrysomelidae). Alabama Experiment Station Bulletin 441, 223 pp.

Bassett, B., D. Menown, and C. Gemming. 1993. Nuisance aquatic plants in Missouri ponds and lakes. Missouri Conservationist.

Berg, C. O. 1949. Limnological relations of insects to plants of the genus Potamogeton. Transactions of American Microscopical Society 68: 279-291.

Borror, D. J ., D. M. DeLong, and C. A. Triplehorn. 1976. An introduction to the study of insects. 4th ed. New York: Hold, Rinehart, and Winston.

Buckingham, G. R., and B. M. Ross. 1981. Notes on the biology and host specificity of Acentria nivea (=Acentropus niveus). Journal of Aquatic Plant Management 19: 32-36.

Buckingham, G. R., and C. A. Bennett. 1989. Laboratory host range of Parapoynx diminutalis (Lepidoptera; Pyralidae), as Asian aquatic moth adventive in Florida and Panama on Hydrilla (Hydrocharitaceae). Environmental Entomologist 18(3): 526-530.

Buckingham, G. R., and C. A. Bennett. 1996. Laboratory biology of an immigrant Asian Moth, Parapoynx diminutalis (Lepidoptera; Pyralidae), on Hydrilla (Hydrocharitaceae). Florida Entomologist 79(3).

Carpenter, S. R., and D. M. Lodge. 1986. Effects of submersed macrophytes on ecosystem processes. Aquatic Botany 26: 341-370.

Cassani, J . R. 1985. Biology of Simyra henrici (Lepidoptera: Noctuidae) in southwest Florida. Florida Entomologist 68: 645-652.

Center, T. D., and R. L. Kipker. 1991. First record in Floridas of Acanthoscelides quadridentatus (Coleoptera: Bruchidae), a potential biological control agent of Mimosa pigra. Florida Entomologist 74: 159-162. 
Center, T. D., F. A. Dray, J r., G. P. J ubinsky, and M. J . Grodowitz. 1999. Insects and other arthropods that feed on aquatic and wetland plants. Technical Bulletin No. 1870. U.S. Department of Agriculture, Agricultural Research Service.

Center, T. D., F. A. Dray, and V. V. Vanidiver, Jr. 2002. Biological control with insects: The Asian hydrilla moth. SS AGR 139. Department of Agronomy, Florida Cooperative Extension Service, Institute of Food and Agricultural Sciences, University of Florida.

Chester, E. W., and S. E. Hold. 1990. The Uruguayan water-primrose (Ludwigia uruguayensis) in Tennessee and Kentucky. Journal of the Tennessee Academy of Science 65(1): 9-12.

Clark, W. E. 1976. Notes on the life history and habits of Perigaster cretura (Herbst) (Coleoptera: Curculionidae) with descriptions of the larva and pupa. The Coleopterists Bulletin 30(2): 159-165.

Creed, R. P. 2000. The weevil-watermilfoil interaction at different spatial scales: What we know and what we need to know. Journal of Aquatic Plant Management 38: 78-81.

Creed, R. P., and S. P. Sheldon. 1994a. Aquatic weevils (Coleoptera: Curculionidae) associated with watermilfoil (EWM) in Alberta, Canada. Entomol. News 105: 98-102.

1994b. Potential for a native weevil to serve as a biological control agent for Eurasian watermilfoil. Technical Report A-94-7. Vicksburg, MS: U.S. Army Engineer Waterways Experiment Station.

Cronin, G., K. D. Wissing, and D. M. Lodge. 1998. Comparative feeding selectivity of herbivorous insects on water lilies: Aquatic vs. semi-terrestrial insects and submersed vs. floating leaves. Freshwater Biology 39: 243-257.

Delfosse, E. S., B. D. Perkins, and K. K. Steward. 1976. A new U.S. record for Parapoynx diminutalis (Lepidoptera: Pyralidae), a possible biological control agent for Hydrilla. Florida Entomologist 59: 19-20.

Deonier, D. L. 1971. A systematic and ecological study of Nearctic hydrellia (Diptera: Ephydridae). Number 68. Smithsonian Contributions to Zoology.

DiTomaso, J. M., and E. A. Healy. 2003. Aquatic and riparian weeds of the West. Publication 3421. University of California Agriculture and Natural Resources.

English Nature. 1999. Overgrown and over here! Press release, 15 September 1999.

Ensbey, R. 2000. Cabomba: identification and management of cabomba species. Agnote - NSW Agriculture.

Fairchild, D. G. 1944. Garden islands of the great east: collecting seeds from the Philippines and Netherlands-India in the Junk Cheng Ho. New York: Scribner and Son, $239 \mathrm{pp}$.

Floate, K. D., and T. G. Whitham. 1994. Aphid-ant interaction reduces Crysomelid beetle herbivory in a cottonwood hybrid zone. Oecologia 97: 215-221. 
Forno, I. W., D. P. A. Sands, and W. Sexton. 1983. Distribution, biology and host specificity of Cyrtobagous singularis Hustache (Coleoptera: Curculionidae) for the biological control of Salvinia molesta. Bulletin of Entomological Research 73: 85-95.

Fritz, R. S., C. M. Nichols-Orians, and S. J . Brunsfeld. 1994. Interspecific hybridization of plants and resistance to herbivores: hypothesis, genetics, and variable responses in a diverse herbivore community. Oecologia 97: 106-117.

Goeden, R. D. 1977. Chapter 4 - Biological control of weeds. In Research methods in weed science. 2nd ed. Southern Weed Science Society.

Grodowitz, M. J., C. S. Owen, R. M. Smart, and J . M. Graham. 2007. Impact of herbivory and plant competition on the growth of hydrilla in small ponds. ERDC/TN APCRP-BC-08. Vicksburg, MS: U.S. Army Engineer Research and Development Center.

Gross, E. M., R. L. J ohnson, and N. G. Hairston, Jr. 2001. Experimental evidence for changes in submersed macrophyte species composition caused by the herbivore Acentria ephemerella (Lepidoptera). Oecologia 127: 105-114.

Gunner, H. B. 1983. Microbiological control of Eurasian watermilfoil. In Proceedings, 17th Annual Meeting Aquatic Plant Control Research Program. Miscellaneous Paper A-83-3. Vicksburg, MS: U.S. Army Engineer Waterways Experiment Station.

Gunner, H. B., Y. Limpa-amara, B. S. Bouchard, P. J . Weilerstein, and M. E. Taylor. 1990. Microbiological control of Eurasian watermilfoil. Technical Report A-90-2. Vicksburg, MS: U.S. Army Engineer Waterways Experiment Station.

Habeck, D. H. 1991. Synclita obliteralis (Walker), the waterlily leafcutter (Lepidoptera: Pyralidae: Nymphulinae). Entomology Circular 345. Gainesville, FL: Florida Department of Agriculture and Consumer Services, Division of Plant Industry.

Habeck, D. H., and R. Wilderson. 1980. The life cycle of Lysathia ludoviciana (Fall) (Coleoptera: Chrysomelidae) on Parrotfeather, Myriophyllum aquaticum (Velloso) Verde. The Coleopterists Bulletin 34(2): 167-170.

Hairston, N.G., J r., and R. L. J ohnson. 2001. Monitoring and evaluating the impacts of herbivorous insects on Eurasian watermilfoil. Report to New York State Department of Environmental Conservation, Division of Fish and Wildlife. Ithaca, NY: Cornell University.

Harley, K. L. S., and I. W. Forno. 1992. Biological control of weeds, a handbook for practitioners and students. Melbourne: Inkata Press.

Harley, K. L. S. 1985. Suppression of reproduction of woody weeds using insects which destroy flowers or seeds. In Proceedings of the VI International Symposium on Biological Control of Weeds, Aug. 19-25, 1984, Vancouver, Canada. E.S. Delfosse, ed., 749-756. Agriculture Canada. 
Hoyme, D. P., J . F. Grant, and P. L. Lambdin. 2001. Leaf consumption by a North American flea beetle, Altica litigata, and its impact on purple loosestrife, Lythrum salicaria. Abstract 0316, Entomological Society of American Annual Meeting, December 9-12, 2001, San Diego, CA.

Invasive Species Specialist Group (ISSG) Global Invasive Species Database. 2006. http:// www.issg.org.database

J ester, L. L. M. A. Bozek, D. R. Helsel, and S. P. Sheldon. 2000. Euhrychiopsis lecontei distribution, abundance, and experimental augmentations for Eurasian watermilfoil control in Wisconsin lakes. Journal of Aquatic Plant Management 38: 88-97.

J ohnson, C. D. 1983. Ecosystematics of Acanthoscelides (Coleoptera: Bruchidae) of southern Mexico and Central America. Entomol. Soc. Am. 56: 1-370.

Johnson, R. L., and B. Blossey. 2002. Eurasian watermilfoil. In Biological Control of Invasive Plants in the Eastern United States. R. V. Driesche, S. Lyon, B. Blossey, M. Hoddle, and R. Reardon, ed. FHTET-2002- 04. USDA Forest Service.

J ohnson, R. L., E. M. Gross, and N. G. Hairston, Jr. 1998. Decline of the invasive submersed macrophyte EWM (Haloragaceae) associated with herbivory by larvae of Acentria ephemerella (Lepidoptera). Aquatic Ecology 31: 273-282.

J ohnson, R. L., P. J . VanDusen, J . A. Toner, and N. G. Hairston, Jr. 2000. Eurasian watermilfoil biomass associated with insect herbivores in New York. Journal of Aquatic Plant Management 38: 82-88.

J oye, G. F. 1988. Biological control of Hydrilla verticillata (L.f.) Royle using an endemic fungal plant pathogen. Phytopathology 78: 1593 (A642).

1989. Biological control of Hydrilla verticillata (L.f.) Royle using endemic plant pathogen. In Proceedings, 23rd Annual Meeting, Aquatic Plant Control Research Program. Miscellaneous Paper A-90-1, 41-51. Vicksburg, MS: U.S. Army Engineer Waterways Experiment Station.

. 1990. Biocontrol of Hydrilla with the endemic fungus Macrophomina phaseolina. Plant Disease 74: 1035-1036.

J oye, G. F., and A. F. Cofrancesco, Jr. 1991. Studies on the use of fungal plant pathogens for control of Hydrilla verticillata (L.f.) Royle. Technical Report A-91-4. Vicksburg, MS: U.S. Army Engineer Waterways Experiment Station.

J oye, G. F., and R. N. Paul. 1992. Histology of infection of Hydrilla verticillata by Macrophomina phaseolina. Weed Science 40: 288-295.

Julien, M. H., and M. W. Griffiths. 1999. Biological control of weeds: A world catalogue of agents and their target weeds. 4th ed. New York: CABI Pub.

Julien, M. H., T. D. Center, and P. W. Tipping. 2002. Floating fern (Salvinia). In Biological control of invasive plants in the eastern United States. R. V.Driesche, S. Lyon, B. Blossey, M. Hoddle, and R. Reardon, ed. FHTET - 2002- 04. USDA Forest Service. 
Kassulke, R. C., K. L. S. Harley, and G. V. Maynard. 1990. Host specificity of Acanthoscelides quadridentatus and A. puniceus (Col.: Bruchidae) for biological control of Mimosa pigra (with preliminary data on their biology). Entomophaga 35: 85-96.

Kinser, P. D., and H. H. Neunzig. 1981. Descriptions of the immature stages and biology of Synclita tinealis Munroe (Lepidoptera: Pyralidae: Nymphulinae). Journal of the Lepidopterists' Society 35: 137-146.

Lange, W. H., Jr. 1956. A generic revision of the aquatic moths of North America: (Lepidoptera: Pyralidae: Nymphulinae). Wasserman Journal of Biology 14(1): 59-143.

Lillie, R. A. 2000. Temporal and spatial changes in milfoil distribution and biomass associated with weevils in Fish Lake, WI. J ournal of Aquatic Plant Management 38: 98-104.

Lonsdale, W. M., K. L. S. Harley, and J. D. Gillett. 1988. Seed bank dynamics in Mimosa pigra, an invasive tropical shrub. Journal of Applied Ecology 25: 963-976.

Mackey, A. P., and J. T. Swarbrick. 1997. The biology of Australian weeds 32. Cabomba caroliniana Gray. Plant Protection Quarterly 12: 154-165.

Madsen, J. D., H. A. Crosson, K. S. Hamel, M. A. Hilovsky, and C. H. Welling. 2000. Panel Discussion: Management of Eurasian watermilfoil in the United States using native insects: state regulatory and management issues. Journal of Aquatic Plant Management 38: 121-124.

Mazzei, K. C., R. M. Newman, A. Loos, and D. W. Ragsdale. 1999. Developmental rates of the native milfoil weevil, Euhrychiopsis lecontei, and damage to Eurasian watermilfoil at constant temperatures. Biological Control 16: 139-143.

McCann, J . A., L. N. Arkin, and J . D. Williams. 1996. Nonindigenous aquatic and selected terrestrial species of Florida. National Biological Service, Southeastern Biological Science Center, Gainesville, FL. Published on the Internet by the University of Florida, Center for Aquatic Plants.

McGregor, M. A., D. R. Bayne, J . G. Steeger, E. C. Webber, and E. Reutebuch. 1996. The potential for biological control of water primrose (Ludwigia grandiflora) by the water primrose flea beetle (Lysathia ludoviciana) in the southeastern United States. Journal of Aquatic Plant Management 34: 74-76.

Moody, M. L. and D. H. Les. 2002. Evidence of hybridity in invasive watermilfoil (Myriophyllum) populations. In Proceedings of the National Academy of Sciences of the U.S. of America 99(23): 14867-14871.

Murray, Tom. 2005. Pyraloidea through Pyralinae moths 4703 - 6088. 4755 - Waterlily leafcutter moth, Synclita obliteralis. http:// www.pbase.com/tmurray74/pyraloidea_through_pyralinae_moths. 
Napompeth, B. 1994. Biological control of paddy and aquatic weeds in Thailand. Bangkok,Thailand: National Biological Control Research Center (NBCRC), Kasetsart University.

Nayek, T. K. and T. C. Banerjee. 1987. Life history and host specificity of Altica cynanea (Coleoptera: Chrysomelidae), a potential biological control agent for water primrose, Ludwigia adscendens. Entomophaga 32: 407-414.

Nelson, L. S., and J. F. Shearer. 2002. Response of Eurasian watermilfoil to integrated fluridone-fungal pathogen treatment. APCRP Technical Notes Collection (TN APCRP-IC-03). Vicksburg, MS: U.S. Army Engineer Research and Development Center.

Nelson, L. S., and J. F. Shearer. 2005. 2,4-D and Mycoleptodicus terrestris for control of Eurasian Watermilfoil. Journal of Aquatic Plant Management 43: 29-34.

Nelson, L. S., J . F. Shearer, and M. D. Netherland. 1998. Mesocosm evaluation of integrated fluridone-fungal pathogen treatment on four submersed plants. Journal of Aquatic Plant Management 36: 73-77.

Netherland, M. D., and J. F. Shearer. 1996. Integrated use of fluridone and a fungal pathogen for control of hydrilla. Miscellaneous Paper A-96-1. Vicksburg, MS: U.S. Army Engineer Waterways Experiment Station.

Newman, J . F. 2004. Floating Pennywort. Information Sheet 24. Center for Ecology and Hydrology, Natural Environment Research Council, Centre for Aquatic Plant Management, Wallingford, Crowmarsh Gifford, Wallingford, Oxon, U.K.

Newman, J. R., and F. H. Dawson. 1999. Ecology, distribution and chemical control of Hydrocotyle ranunculoides in the U.K. Hydrobiologia 415: 295-298.

Newman R. M. 1991. Herbivory and detritivory on freshwater macrophytes by invertebrates: A review. Journal of North American Benthological Society 10(2): 89-114.

Northern NewYork Agricultural Development Program. 1999. Acentria ephermerella (a.k.a. Milfoil Moth). http:// www.nny.org/articles/watermilfoil.htm.

Schardt, J . D., and D. C. Schmitz. 1990. 1990 Florida aquatic plant survey report. Tallahassee: Florida Department of Natural Resources.

Schooler, S. S., D. G. Williams, K. Stokes, and M. J ulien. 2005. 8th International River Symposium 2005. Brisbane, Australia.

Schultz, P. B., D. O. Gilrein, and M. S. Dills. 2001. Flea beetles damaging perennials. In Proceedings of the Southern Nursery Association, Inc., Forty-Sixth Annual Report, 190-191.

Shearer, J . F. 1994. Field test of first commercial formulation of Mycoleptodiscus terrestris (Gerd.) Ostazeski as a biocontrol for Eurasian watermilfoil. Miscellaneous Paper A-94-4. Vicksburg, MS: U.S. Army Engineer Waterways Experiment Station. 
Shearer, J. F. 1996a. Field and laboratory studies of the fungus Mycoleptodiscus terrestris as a potential agent for management of the submersed aquatic macrophyte Hydrilla verticillata. Technical Report A-96-3. Vicksburg, MS: U.S. Army Engineer Waterways Experiment Station.

- 1996b. Potential of a pathogen, Mycoleptodiscus terrestris, as a biocontrol agent for the management of Myriophyllum spicatum in Lake Guntersville Reservoir. Technical Report A-96-4. Vicksburg, MS: U.S. Army Engineer Waterways Experiment Station.

. 1997. Classical pathogen biocontrol research in Asia 1994-1995: Surveys for pathogen agents of Hydrilla verticillata (L.f.) Royle and Myriophyllum spicatum L. Technical Report A-97-1. Vicksburg, MS: U.S. Army Engineer Waterways Experiment Station.

Shearer, J . F., and L. S. Nelson. 2002. Integrated use of endothall and a fungal pathogen for management of the submersed macrophyte Hydrilla verticillata (L.f.) Royle. Weed Technology 16: 224-230

Sheppard, A. D. 1945. A new record for Canada (Lepidoptera). Canadian Entomologist 77: 55.

Smart, R. M. 1992. Competition interactions among introduced and native species. In Proceedings, 26th Annual Meeting of Aquatic Plant Control Research Program, 154-159. Miscellaneous Paper A-92-2. Vicksburg, MS: U.S. Army Engineer Waterways Experiment Station.

. 1993. Competition among introduced and native species. In Proceedings, 27th Annual Meeting of Aquatic Plant Control Research Program, 235-241. Miscellaneous Paper A-93-2. Vicksburg, MS: U.S. Army Engineer Waterways Experiment Station.

Smart, R. M., and R. Doyle. 1995. Ecological theory and the management of submersed aquatic plant communities. Miscellaneous Paper A-95-3. Vicksburg, MS: U.S. Army Engineer Waterways Experiment Station.

Smart, R. M., J. B. Barko, and D. G. McFarland. 1994. Competition between Hydrilla verticillata and Vallisneria americana under different environmental conditions. Technical Report A-94-1. Vicksburg, MS: U.S. Army Engineer Waterways Experiment Station.

Smith, C. S., and L. E. Winfield. 1991. Biological control of Eurasian watermilfoil using plant pathogens. In Proceedings 25th Annual Meeting Aquatic Plant Control Research Program. Miscellaneous Paper A-91-3. Vicksburg, MS: U.S. Army Engineer Waterways Experiment Station.

Solarz, S. L., and R. M. Newman. 2001. Variation in hostplant preference and performance by the milfoil weevil, Euhrychiopsis lecontei Dietz, exposed to native and exotic watermilfoils. Oecologia 126: 66-75. 
Stack, J. P. 1990. Development of the fungal agent Mycoleptodiscus terrestris for the biological control of Eurasian watermilfoil (Myriophyllum spicatum L.). In Proceedings 24th Annual Meeting Aquatic Plant Control Research Program. Miscellaneous Paper A-90-3. Vicksburg, MS: U.S. Army Engineer Waterways Experiment Station.

Tamayo, M., C. E. Grue, and K. Hamel. 2000. The relationship between water quality, watermilfoil frequency, and weevil distribution in the state of Washington. Journal of Aquatic Plant Management 38: 112-116.

U.S. Army Engineer Research and Development Center (ERDC). 2005. Aquatic Plant Information System (APIS). http://el.erdc.usace.army.mil/aqua/ apis/ apishelp.htm.

USDA, NRCS. 1999. United States Department of Agriculture, Natural Resources Conservation Service. Plants Database. http:// plants.usda.gov (accessed in 2000).

VanDusen, P.J . 2003. Computing at Cornell. http:// www.people.cornell.edu/ pages/pjv2/. Cornell Ponds. http:// www/ eeb.cornell.edu/ponds/index.html . Acentria ephemerella (Lepidoptera: Pyralidae) http:// www.people.cornell.edu/ pages/pjv2/acentria/catinfo.html.

Washington State Department of Ecology (WSDE). 2003. Programs; Water Quality; Aquatic Plants and Lakes; Non-Native, Invasive Aquatic Plants; Technical information about parrotfeather (Myriophyllum aquaticum). http:/ / www.ecy.wa. gov/ programs/ wq/ plants/ weeds/ aqua003.html.

Welch, P. S. 1919. The aquatic adaptations of Pyrausta penitalis Grt. (Lepidoptera). Annals of the Entomological Society of America 12: 213-226.

Wells, D. S. R., M. D. De Winton, and J . S. Clayton. 1997. Successive macrophyte invasions within the submerged flora of Lake Tarawera, Central North Island, New Zealand. New Zealand Journal of Marine and Freshwater Research 31: 449-459.

Whetstone, J. M., D. L. Robinette, and B. Polomski. 2000. Aquatic plant selection. Home and Garden Information Center, Clemson University Cooperative Extension Service, HGIC 1709, http:// hgic.clemson.edu.

Whitham, T. G., G. D. Martinsen, K. D. Floate, H. S. Dungey, B. M. Potts, and P. Klein. 1999. Plant hybrid zones affect biodiversity: Tools for a genetic-based understanding of community structures. Ecology 80: 416-428.

Wiggins, G. B. 1977. Larvae of the North American Caddisfly Genera (Trichoptera). Toronto: University of Toronto Press. 


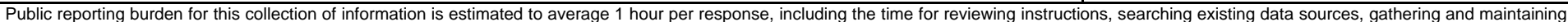

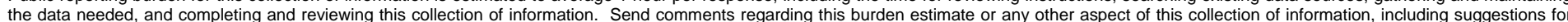

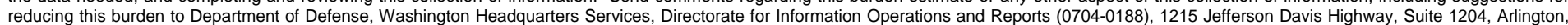

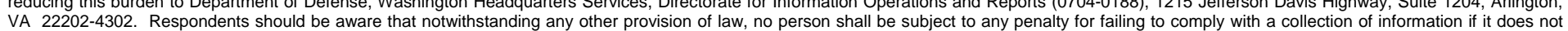
VA 22202-4302. Respondents should be aware that notwithstanding any other provision of law, no person shall be sube
display a currently valid OMB control number. PLEASE DO NOT RETURN YOUR FORM TO THE ABOVE ADDRESS.

\begin{tabular}{l|c}
$\begin{array}{l}\text { 1. REPORT DATE (DD-MM-YYYY) } \\
\text { August } 2007\end{array}$ & $\begin{array}{c}\text { 2. REPORT TYPE } \\
\text { Final report }\end{array}$ \\
\hline
\end{tabular}

\section{TITLE AND SUBTITLE}

Potential Use of Native and Naturalized Insect Herbivores and Fungal Pathogens of Aquatic and Wetland Plants

3. DATES COVERED (From - To)

5a. CONTRACT NUMBER

5b. GRANT NUMBER

5c. PROGRAM ELEMENT NUMBER

5d. PROJECT NUMBER

5e. TASK NUMBER

5f. WORK UNIT NUMBER

8. PERFORMING ORGANIZATION REPORT NUMBER

ERDC/EL TR-07-11

U.S. Army Engineer Research and Development Center, Environmental Laboratory, 3909 Halls Ferry Road, Vicksburg, MS 39180-6199;

Baylor University, Waco, TX 76704;

Lewisville Aquatic Ecosystem Research Facility, Lewisville, TX 75057

\section{SPONSORING I MONITORING AGENCY NAME(S) AND ADDRESS(ES)}

U.S. Army Corps of Engineers

Washington, DC 20314-1000
10. SPONSOR/MONITOR'S ACRONYM(S)

11. SPONSOR/MONITOR'S REPORT NUMBER(S)

\section{DISTRIBUTION / AVAILABILITY STATEMENT}

Approved for public release; distribution is unlimited.

\section{SUPPLEMENTARY NOTES}

\section{ABSTRACT}

Research is being conducted by U.S. Army Engineer Research and Development Center (ERDC) scientists to identify naturalized and/or native herbivores of aquatic plants in an effort to develop alternative management strategies through an understanding of the agents' biology and ecology. Some of the native species showing promise as biocontrol agents include Altica spp. for water primrose, Donacia spp. for American lotus, and Euhrychiopsis lecontei for Eurasian watermilfoil control. Naturalized species with possibility include Cyrtobagus salviniae for common and giant salvinia, and Parapoynx diminutalis for hydrilla. Information is presented herein for selected native and naturalized agents that may potentially be used to impact and manage all types of aquatic and wetland plant species including introduced, naturalized, and native species. Native and naturalized insect herbivores and fungal pathogens discussed include: Acanthoscelides quadridentatus, Acentria ephemerella, Altica spp., Cyrotobagous salviniae, Donacia spp., Euhrychiopsis lecontei, Hydrellia bilobifera Cresson, and $H$. discursa Deonier, Mycoleptodiscus terrestris, Ostrinia penitalis, Parapoynx diminutalis, Pergaster cretura, Simyra henrici, and Synclita oblieralis.

\section{SUBJECT TERMS}

Aquatic plants

American lotus

16. SECURITY CLASSIFICATION OF:

\begin{tabular}{|l|l|}
\hline a. REPORT & b. ABSTRACT \\
UNCLASSIFIED & UNCLASSIFIED \\
\hline
\end{tabular}

Biocontrol agents

Eurasian watermilfoil

Fungal pathogens

17. LIMITATION

c. THIS PAGE

UNCLASSIFIED 17. LIMITATION
OF ABSTRACT
Insect herbivores

Water primrose

18. NUMBER
OF PAGES
62

19a. NAME OF RESPONSIBLE PERSON

19b. TELEPHONE NUMBER (include area code) 